\title{
4 \\ Integriranje dohodkov v sodobni kmečki ekonomiji
}

\author{
Štefan Bojnec \\ Univerza na Primorskem \\ Fakulteta za management \\ Cankarjeva 5, Koper \\ stefan.bojnec@fm-kp.si
}

\section{Uvod}

Integriranje dohodkov v kmečki ekonomiji je bila zgodovinska stalnica (Panjek, Larsson in Mocarelli 2017). V prispevku se osredotočamo na integriranje dohodkov kmečkih in podeželskih gospodarstev v sodobni kmečki ekonomiji. V zadnjih dveh desetletjih so se v evropskem in v slovenskem kmetijstvu zgodile pomembne strukturne spremembe. Med njimi je upad števila kmetij. Povečala sta se število večjih kmetij in njihova povprečna velikost (Bojnec in Latruffe 2013). Ne samo odkup zemljišča, temveč zlasti zakup zemljišč je postal pomemben dejavnik za povečanje števila večjih kmetijskih gospodarstev in povečanje njihove povprečne velikosti. V Sloveniji to kaže na tržno sprostitev tradicionalno močne povezave med družinskim lastništvom kmetijske zemlje ter njeno lastno obdelavo ter obratovanjem na družinskem zemljišču. Zaradi tega so se povečale transakcije na trgu zemlje in zakupa zemljišč. Porast zakupa zemlje je osredotočen na obdelavo zemlje več kmetij, ki so prenehale kmetovati. Za sodoben razvoj je značilno večje število lastnikov zemljišč, kot je upravljavcev in obdelovalcev zemljišč oz. tistih kmetij, ki dejansko obdelujejo zemljo. Ta razvojni vzorec je podoben nekaterim državam v zahodni Evropi, kot sta Belgija in Francija, kjer je delež rabe zemljišč na najetih zemljiščih precejšen.

Velik delež kmetijskih gospodarstev na slovenskih podeželskih območjih je tradicionalno združeval zaposlitvene in dohodkovne dejavnosti na kmetiji in zunaj nje (Knific in Bojnec 2015). Ti vzorci zaposlovanja in 
raznovrstnosti $\mathrm{v}$ dohodkih kmetijskih gospodarstev v gospodarskem razvoju so v skladu s podobnimi gibanji v nekaterih razvitih državah, kot so Francija (Campagne, Carreere in Valceschini 1990), sosednja Italija (Bull in Corner 1993), Japonska (Francks 1995), Irska (Kinsella idr. 200o), kakor tudi v državah v razvoju (Ellis 1998; 200o) in na Kitajskem (van der Ploeg in Jingzhong 2010). Zato je zaposlovanje na kmetiji in zunaj nje s povezanimi dohodkovnimi viri na kmetiji in zunaj nje postalo ena bistvenih značilnosti pri razvoju več delovnih mest v kmetijskih gospodarstvih in na podeželju v njihovih strategijah razvoja v konkurenčnem lokalnem in globalnem gospodarskem okolju.

Teoretična, konceptualna in empirična literatura ter prakse so se razvile na različnih konceptih in značilnostih pluriaktivnosti, kmetovanja $s$ krajšim delovnim časom (angl. part-time farming), diverzifikacije kmetij ter integriranega in vključujočega razvoja podeželja v sodobni ekonomiji. V več državah, med njimi tudi v Sloveniji, je družinsko kmetijstvo oz. kmetija opredeljena z zakonom (Graeub idr. 2016). Definicije družinskih kmetij se med državami razlikujejo (Davis idr. 2010; Graeub idr. 2016). Obstaja tudi velika raznolikost družinskih kmetij na svetovni ravni. Na splošno družinska kmetija opravlja kmetijske dejavnosti predvsem za samoobdelavo: v lasti ima zemljišče, kjer proizvajajo družinski člani, zagotavlja minimalni dohodek iz kmetijskih dejavnosti in opravlja večnamenske (angl. multifunctional) vloge na podeželju. Sodoben razvoj družinske kmetije v razvitih državah pa vse bolj temelji tudi na obdelavi najete zemlje.

Prispevek se osredotoča na oblike in vsebine integriranja dohodkov v sodobni kmečki ekonomiji. Pri tem so prikazane strukturne spremembe v kmetijstvu in na kmetijah ter v sodobni podeželski ekonomiji, ki so povezane $z$ večfunkcionalnostjo kmečkih gospodarstev in kmetijstva s podeželsko ekonomijo, družbo in okoljem, smeri razvoja kmečkih gospodarstev in njihova pluriaktivnost, diverzifikacija kmetijske dejavnosti na različne proizvodne usmeritve in integriranje dohodkov kmečkih gospodarstev $\mathrm{v}$ sodobnem razvoju kmetijstva in podeželske ekonomije. Pregled predhodne literature kaže na interdisciplinarnost analiziranih vprašanj, kar izhaja tudi iz same narave in načinov integriranja dohodkov v sodobni kmečki ekonomiji. Gre za vprašanja, ki so povezana z zgodovinsko-antropološko evolucijo pojava, s pravno-organizacijskimi, $\mathrm{z}$ agrarno-ekonomskimi in s podjetniškimi vidiki ureditve in razvoja dopolnilnih dejavnosti na kmetijah, zaposlovanja in dohodkov izven kmetij ter s tem integriranja dohodkov v sodobni kmečki in podeželski ekonomiji. 


\section{Večfunkcionalnost kmetijstva in smeri integriranja}

\section{dohodkov kmečkih in podeželskih gospodarstev}

Večfunkcionalnost kmetijstva in kmečkih gospodarstev je postal interdisciplinarni in agrarno-politični slogan $\mathrm{v}$ svetovnem kmetijskem razvoju ter $\mathrm{v}$ razvoju podeželja $\mathrm{z}$ zelo različnim pomenom in pojmovanjem (Bojnec 2017). Poleg različnih načinov in virov integriranja dohodkov kmetij lahko v širšem smislu med cilje vključuje prehransko varnost, varno prehrano, blaginjo živali, vrednote na področju kulturne in zgodovinske dediščine, kakovost na področju okolja, podeželske pokrajine, biološko raznolikost in razvoj podeželja kot samo nekatere od rezultatov, ki se povezujejo z večfunkcionalnostjo kmetijskega sektorja in kmečkih gospodarstev v sodobni podeželski ekonomiji. Implikacije za posamezne vladne in lokalne politike, ki se povezujejo in izhajajo iz večfunkcionalnosti kmetijstva ter kmečkih gospodarstev v podeželski ekonomiji, se prav tako precej razlikujejo med posameznimi državami, kar ponazarja, vendar ne presenetljivo, stališča posameznih ekonomskih politik do kmetijske pomoči, subvencij in zaščite kmetijstva. Med več skupinami držav so nekatere države EU-28, vključno Slovenija, tiste, ki so vsaj na formalni ravni močni zagovorniki večfunkcionalnosti kmetijstva in kmečkih gospodarstev v sodobnem razvoju podeželja. To so države, ki, na splošno gledano, zagotavljajo visoke ravni državne pomoči, subvencij in zaščite za domače kmetijske sektorje. Glede na specifičnosti pojava po posameznih državah, regijah in v ožjem lokalnem razvoju obstaja literatura o specifičnih teoretičnih in empiričnih vidikih večfunkcionalnosti kmetijstva ter kmečkih gospodarstev v razvoju podeželja.

Večfunkcionalnost kmetijstva in kmečkih gospodarstev $\mathrm{v}$ razvoju podeželja se povezuje tudi v krožnem gospodarskem razvoju s posebnim odnosom in povezavami med ekonomijo, družbo in naravnim okoljem. Različne vloge, ki jih kmetije in kmetijstvo igrajo na podeželju, se poleg pridelave hrane povezujejo $\mathrm{z}$ različnimi pozitivnimi učinki oz. pozitivnimi eksternalijami, ki so pomembne za naravno okolje (prst, voda in zrak) in prispevajo druge storitve čistega naravnega okolja in urejenosti krajine, kar je pomembno za rekreacijo, razvoj turizma in podobno. Reforme skupne kmetijske politike v Evropski uniji v zadnjih dveh desetletjih so bile osredotočene na preusmeritev ukrepov in subvencij od intervencij in posegov na trgu in $\mathrm{v}$ mednarodni trgovini na direktna plačila za enote kmetijske zemlje ali posamezne živali, ki so postala proizvodno nevezana (steber 1) ter na politike in ukrepe trajnostnega razvoja kmetijstva in podeželja (steber 2) (Bojnec in Fertő 2017). Steber 2 - skupne kmetijske politike v Evropski uniji 
- vključuje tri skupine ukrepov in povezanih subvencij: kmetijsko-okoljske ukrepe, ukrepe, usmerjene na območja $\mathrm{z}$ omejenimi dejavniki za kmetijsko proizvodnjo, in ukrepe za naložbe $\mathrm{v}$ prestrukturiranja kmetijstva in povečanja konkurenčnosti ter razvoja podeželja. Proizvodno nevezane subvencije kmetom naj bi tako bile $\mathrm{v}$ funkciji plačila za pozitivne eksternalije za družbo, ki so usmerjene v vzdrževanje kulturne krajine, poseljenosti podeželja in perifernih hendikepiranih območij, ohranjanje naravnih in okoljskih dejavnikov in podobno, ne pa v samo povečevanje obsega kmetijske proizvodnje.

Razvoj kmečkih gospodarstev gre $v$ smeri diverzifikacije virov zaposlitev, povečane vloge in odvisnosti od državnih in drugih transferjev ter $\mathrm{s}$ tem povečanega integriranja dohodka kmečkih gospodarstev in podeželske ekonomije, kjer je kmetijstvo pomembno, vendar ne nujno glavni vir zaposlitev in dohodkov. Več ustvarjenih zaposlitev $\mathrm{v}$ kmečkih gospodarstvih in v podeželski ekonomiji lahko zmanjša migracije - kot strategija za ohranjanje in razvoj v konkurenčnem lokalnem in globalnem ekonomskem okolju. Pri tem so lahko uporabljeni različni koncepti in značilnosti integriranja dohodkov kmečkih gospodarstev: pluriaktivnost, kmetovanje s krajšim delovnim časom, diverzifikacija kmetij ter integrirani in vključujoči razvoj kmečkega ter podeželskega gospodarstva (Bojnec 2017).

Pluriaktivnost kmetij, $\mathrm{z}$ določenimi specifičnostmi med državami in znotraj med regijami, je prisotnejša v severni kot v južni Evropi. Kmetije $s$ prisotnimi drugimi koristnimi dejavnostmi (angl. farmers with other gainful activities) v državah EU-28 so močno zastopane na Švedskem, v južnem delu Finske, v Veliki Britaniji, na Irskem, v južnem delu Nemčije in Avstrije ter v Sloveniji. Manj zastopane so v delih Grčije, južnem (valonskem) delu Belgije, obmejnih območjih med Francijo in Italijo ter v nekaterih drugih delih Francije in Španije (Eurostat 2017).

Razviti so bili različni koncepti diverzifikacije kmetijske dejavnosti in razvoja podeželskih nekmetijskih dejavnosti v različne smeri, tako v okviru kot zunaj okvira kmetijske zaposlenosti in diverzifikacije ter integriranja dohodkov kmečkih in podeželskih gospodarstev. Različni koncepti so bili razviti $\mathrm{v}$ različnih državah, za njihova posamezna območja in za različna časovna obdobja. To pomeni, da gre pri integriranju dohodkov kmečkih in podeželskih gospodarstev za kompleksen in dinamičen koncept, ki se lahko prostorsko in časovno razlikuje. Zato med državami obstajajo velika teoretična kompleksnost in praktične različice $\mathrm{v}$ evoluciji (Bojnec 2017). Povezanosti med kmetijskimi in nekmetijskimi dejavnostmi na 
kmečkem gospodarstvu in dejavnostmi razvoja podeželja se lahko ustvarjajo v različnih smereh. Med najpomembnejšimi smermi razvoja diverzifikacije kmetijskih dejavnosti, zaposlenosti in dohodkov je pluriaktivnost kmečkih gospodarstev kot povezanosti med kmetijskimi in nekmetijskimi dejavnostmi, ki so se spremenile $\mathrm{v}$ smeri večje kompleksnosti povezav $\mathrm{z}$ različnimi oblikami zaposlenosti in diverzikacijo virov dohodkov. Nato je tu kmetovanje s krajšim delovnim časom (angl. part-time farming) kot (začasna) strategija preživetja kmečkega gospodarstva - v Sloveniji v času socializma imenovana tudi kmet-delavec ali mešano kmečko gospodarstvo -, ki je povezana s pluriaktivnostjo kmečkega gospodarstva $\mathrm{z}$ dvotirno zaposlenostjo dela: redna zaposlitev izven kmetije in zaposlitev na kmetiji po redni zaposlitvi izven kmetije (Krašovec 1982). Diverzifikacija kmečkega gospodarstva skozi različne oblike diverzifikacije z zaposlenostjo na kmetiji in izven nje ter s tem diverzifikacijo dohodkov predstavlja pomemben instrument večfunkcionalnosti podeželskih območij. Številna podeželska gospodarstva, ki so bila včasih kmečka, ostajajo podeželska z nekmetijsko zaposlenostjo in diverzifikacijo dohodkov izven kmetijske dejavnosti.

Nekmetijska zaposlenost kmečkim in nekmečkim podeželskim gospodarstvom prinaša redni mesečni dohodek, kot je plača in pozneje pokojnina. Nekmetijska samozaposlenost lahko predstavlja način podeželskega podjetništva, ki prispeva več delovnih mest in dohodkov v podeželskih vaseh. Povezanosti med podeželsko in širšo urbano (globalno) ekonomijo predstavljajo različni medsebojni krožni tokovi, kot so povezava zaposlenosti in tokovi dohodkov med mesti in podeželjem, ki vodijo do prilivov nakazil v podeželska območja.

Različni motivi in determinante so lahko pomembni za nekmetijsko zaposlenost kmečkih in podeželskih gospodarstev, kot so višji donosi dela in/ali kapitala v nekmetijskem gospodarstvu, večji riziki, povezani z zaposlitvijo dejavnikov kmetijske proizvodnje, in nepopolni trgi za kmetijsko-živilske proizvode, ki vodijo v večje nestabilnosti kmetijskih dohodkov v primerjavi z nekmetijskimi dohodki. Na ponudbeni strani se je zaradi tehnološkega napredka $\mathrm{v}$ kmetijstvu močno povečala produktivnost dejavnikov zaposlenih v kmetijstvu, kar omogoča, da precej manj zaposlenih lahko ohranja ali celo povečuje kmetijsko proizvodnjo, pri čemer se $\mathrm{z}$ ukrepi kmetijske politike poskušajo ohranjati obdelana tudi območja, ki bi v večji meri lahko prešla iz kmetijske proizvodnje $\mathrm{v}$ zaraščanje. V Sloveniji naj bi se površine kmetijskih zemljišč $\mathrm{v}$ zaraščanju in neobdelanih kmetijskih zemljišč v zadnjih letih zmanjšale. V letu 2010 naj bi 
bilo zaraščenih in neobdelanih 32.659 hektarjev (ha) kmetijskih zemljišč, medtem ko v letu 2016 okrog 15.060 ha kmetijskih zemljišč. Večji delež kmetijskih površin $\mathrm{v}$ zaraščanju so imela kmetijska gospodarstva, ki so opustila kmetijsko dejavnost ali niso izpolnjevala zahtevanih statističnih meril za njihovo spremljanje. Del kmetijskih zemljišč v zaraščanju pa so postala gozdna zemljišča (SURS 2017).

\section{Integriranje dohodkov kmečkih gospodarstev z dopolnilnimi dejavnostmi na kmetiji}

Pri vprašanju integriranja dohodkov kmečkih gospodarstev $\mathrm{z}$ dohodki od kmetovanja, prejetimi subvencijami in dohodki od dela izven kmetijskih dejavnosti kakor tudi pri vprašanju obdavčenja posamezne dejavnosti in dohodkov na kmetiji se postavi tudi vprašanje opredelitve kmetije oz. kmečkega gospodarstva. Podobno kot ni enotno urejena definicija in opredelitev kmetije, tudi ni enotno urejena opredelitev dopolnilne dejavnosti na kmetiji. Dopolnilna dejavnost na kmetiji je po "Zakonu o kmetijstvu" (Uradni list RS, št. 45/o8, 57/12, 9o/12, 26/14, 32/15) s kmetijstvom oz. gozdarstvom povezana dejavnost, ki kmetiji omogoča boljšo rabo njenih proizvodnih zmogljivosti in delovne moči kmetije ter pridobivanje dodatnega dohodka na kmetiji. »Zakon o kmetijstvu« določa najvišji možni letni dohodek iz dopolnilne dejavnosti - oz. iz vseh registriranih dopolnilnih dejavnosti - na polnoletnega člana kmetije, ki ne sme preseči treh povprečnih letnih plač zaposlenega $v$ Sloveniji v preteklem letu, pri čemer so izjema območja $\mathrm{z}$ omejenimi možnostmi za kmetijsko dejavnost, kjer je omejitev pet povprečnih letnih plač zaposlenega $v$ Sloveniji. V praksi je takšna opredelitev precej ohlapna, da definira in zajame kompleksna vprašanja, ki so povezana $\mathrm{z}$ motivi in aktivnostmi dopolnilnih dejavnosti na kmetiji.

Opredelitev dopolnilnih dejavnosti na kmetiji tudi ni enotno urejena med državami EU-28 glede obsega, pogojev in integriranja dohodkov, opravljanja dopolnilnih dejavnosti na kmetiji in diverzifikacije dohodka ter razmejitve med kmetijsko dejavnostjo, dopolnilno in drugo podjetniško dejavnostjo na kmečkem gospodarstvu in na podeželju. Gre za dejavnosti in subjekte, ki so registrirani kot dopolnilna dejavnost na kmetiji, in subjekte, ki so registrirani kot gospodarske družbe, ki vključujejo razne vrste podjetij in samostojnih podjetnikov. Razmejitev med kmetijsko dejavnostjo in dopolnilno dejavnostjo je pomembna s pravno-organizacijskega in $\mathrm{z}$ ekonomskega vidika $\mathrm{z}$ možnimi vzroki in posledicami ter učinki za razvoj števila kmetij, ki se ukvarjajo $\mathrm{z}$ dopolnilno dejavnostjo, in najpogostejših 
tipov ter obsegov posameznih dopolnilnih dejavnosti. Sam razvoj je lahko povezan $\mathrm{z}$ obdavčitvijo in obremenitvijo s prispevki za socialno varstvo ter njihovim vplivom na dohodek iz dopolnilnih dejavnosti. Sam razvoj dopolnilnih dejavnosti na kmetiji je lahko povezan še z drugimi dejavniki, kot sta ciljno usmerjeno trženje in promocija, ki prispevajo k razvoju dopolnilnih dejavnosti na kmetijah z možnostjo diverzifikacije dohodkov od prodaje diverzificiranih in trgu zanimivih produktov ali storitev.

\section{Strukturne spremembe na kmetijskih gospodarstvih, v kmetijstvu in na podeželju}

Kmetijska gospodarstva, kmetijstvo in podeželska gospodarstva doživljajo občutne strukturne spremembe, ki se kažejo v spremenjeni uporabi dejavnikov kmetijske proizvodnje $\mathrm{z}$ manj dela in več kapitala ter $\mathrm{v}$ spremenjeni strukturi proizvodov in storitev. V preteklosti so na strukturne spremembe $v$ kmetijstvu pomembno vplivale kmetijsko-zemljiške reforme, ki so bile povezane s političnimi in institucionalnimi spremembami; na primer, $\mathrm{v}$ letih po drugi svetovni vojni in $\mathrm{v}$ začetku devetdesetih let prejšnjega stoletja na današnjem ozemlju Slovenije. Na družinskih kmetijah je bila posebej močna družinska povezanost med lastništvom in obdelavo zemlje. Hkrati so v času socializma obstajale institucionalne omejitve glede velikosti družinske kmetije.

Najnovejše strukturne spremembe na kmečkih gospodarstvih in $\mathrm{v}$ kmetijstvu so povezane $\mathrm{z}$ razvojem trga zemlje in trgom zakupa zemlje, kar vodi do pomembnega razlikovanja med lastništvom in obdelavo zemlje na družinskih kmetijah. Prevzemi kmetij v opuščanju obdelave in zakup obdelave zemlje s strani mlajših, vitalnejših kmetij so postali pomembna značilnost najnovejših strukturnih sprememb v kmetijstvu in na kmetijskih gospodarstvih. Opuščanje kmetovanja je poleg izstopanja iz kmetovanja zaradi demografskih razlogov (starost in smrtnost) povezano tudi z novo strukturo zaposlenosti na kmečkem in drugem podeželskem gospodarstvu $\mathrm{v}$ nekmetijskih dejavnostih in s povečano zaposlenostjo $\mathrm{v}$ različnih dejavnostih izven kmetije. Različne vrste zaposlenosti vodijo do različnih novih virov dohodkov, povezanih $\mathrm{z}$ razvojem novih dejavnosti na podeželju, ki ustvarjajo nove vrste dohodkov za kmečka in druga podeželska gospodarstva.

Strukturne spremembe v kmetijstvu in spremembe v velikostni strukturi kmetij se lahko merijo na različne načine. V preteklosti je bila to zlasti velikost kmetijske zemlje ali pa obdelovalne kmetijske površine, ki jo 
kmetija ima v lasti ali pa jo obdeluje. V primeru kmetij, usmerjenih v živinorejo, je lahko pomembna tudi velikost črede, ki je običajno izražena $\mathrm{v}$ enotah živali ali pa $\mathrm{v}$ posameznih vrstah rejenih živali. $\mathrm{V}$ novejšem času se velikost kmetije pogosto izraža v ekonomski velikosti oz. v enotah evropske velikosti (angl. European Size Unit, ESU, pri čemer en ESU predstavlja 1.200 evrov standardne bruto marže, angl. Standard Gross Margin, SGM). Mogoči so še drugačni načini merjenja velikosti kmetij, na primer glede na število zaposlenih ali pa glede velikosti kapitala, ki ga uporablja kmetijsko gospodarstvo.

\section{Kmetijska proizvodnja in spreminjanje števila kmetijskih gospodarstev}

Velikost kmetijske proizvodnje v posamezni državi je poleg same razvitosti kmetijstva in konkurenčnih prednosti države za kmetijsko proizvodnjo odvisna od velikosti države. Med državami EU-28 je bil standardni proizvod velikosti vrednosti kmetijske proizvodnje v letu 2013 največji v Franciji (56,9 milijarde evrov), sledijo Nemčija (46,3 milijarde evrov), Italija ( 43,8 milijarde evrov), Španija (36,o milijard evrov), Velika Britanija (21,9 milijard evrov), Poljska (21,8 milijarde evrov), Nizozemska (20,5 milijarde evrov) in Romunija (12,o milijard evrov). Slovenski standardni proizvod kmetijstva znaša nekaj več kot eno milijardo evrov in se uvršča na 23. mesto, pred Estonijo, Ciprom, Latvijo, Luksemburgom in Malto (Eurostat 2017).

\section{Tabela 4.r: Število kmetijskih gospodarstev v Sloveniji}

\begin{tabular}{lccccccc} 
& 2000 & 2003 & 2005 & 2007 & 2010 & 2013 & 2016 \\
\hline Kmetijska gospodarstva & 86.467 & 77.149 & 77.175 & 75.340 & 74.646 & 72.377 & 69.902 \\
\hline Kmetijska podjetja & 131 & 112 & 133 & 131 & 221 & 201 & 231 \\
\hline Družinske kmetije & 86.336 & 77.037 & 77.042 & 75.209 & 74.425 & 72.176 & 69.671 \\
\hline
\end{tabular}

\section{Vir: SURS 2017.}

Med državami EU-28 obstajajo razlike v spreminjanju števila kmetijskih gospodarstev. V letu 2013 je bilo v državah EU-28 10,84 milijona kmetij. Od tega jih je bilo največ v Romuniji (3,63 milijona), na Poljskem $(1,43$ milijona) in v Italiji (1,1 milijona) (Eurostat 2017). V Sloveniji jih je bilo 72.400. Iz tabele 4.1 je razvidno, da se je število kmetijskih gospodarstev 
v Sloveniji od leta 2000 do leta 2016 zmanjšalo zaradi zmanjšanja števila družinskih kmetij, medtem ko se je manjše število kmetijskih podjetij po vstopu Slovenije v Evropsko unijo po letu 2004 povečalo.

Če so bile strukturne spremembe na kmetijskih gospodarstvih po vstopu Slovenije v Evropsko unijo občutnejše v vzhodni kot pa v zahodni slovenski kohezijski regiji, so v najnovejših letih opazne strukturne spremembe tudi v zahodni kohezijski regiji (tabela 4.2). To velja tako za zmanjševanje števila kmetijskih gospodarstev kot tudi za zmanjševanje kmetijskih zemljišč $\mathrm{v}$ uporabi, ki so se $\mathrm{v}$ zadnjih letih povečale $\mathrm{v}$ vzhodni Sloveniji in zmanjšale $\mathrm{v}$ zahodni Sloveniji. Ekonomska velikost kmetijskih gospodarstev je precej večja v vzhodni kot pa v zahodni kohezijski regiji. Podobno velja za polnovredne delovne moči (PDM), ki se ciklično spreminjajo s tendenco zmanjševanja, kar velja tako za vzhodno kot za zahodno kohezijsko regijo.

Tabela 4.2: Kmetijska gospodarstva po kohezijskih regijah v Sloveniji

\begin{tabular}{|c|c|c|c|}
\hline & Slovenija & Vzhodna Slovenija & Zahodna Slovenija \\
\hline \multicolumn{4}{|l|}{2007} \\
\hline Število kmetijskih gospodarstev & $75 \cdot 340$ & 53.657 & 21.683 \\
\hline Ekonomska velikost (SGM v ESU) & $447 \cdot 743$ & 331.356 & 116.387 \\
\hline Polnovredne delovne moči, PDM & 83.950 & 59.842 & 24.108 \\
\hline Kmetijska zemljišča v uporabi, ha & 488.774 & 340.014 & 148.761 \\
\hline \multicolumn{4}{|l|}{2010} \\
\hline Število kmetijskih gospodarstev & 74.646 & 52.647 & 21.999 \\
\hline Polnovredne delovne moči, PDM & 77.012 & 54.781 & 22.231 \\
\hline Kmetijska zemljišča v uporabi, ha & 474.432 & 337.389 & 137.043 \\
\hline \multicolumn{4}{|l|}{2013} \\
\hline Število kmetijskih gospodarstev & 72.377 & 50.580 & 21.798 \\
\hline Polnovredne delovne moči, PDM & 82.746 & 58.963 & 23.783 \\
\hline Kmetijska zemljišča v uporabi, ha & 477.023 & 336.508 & 140.515 \\
\hline \multicolumn{4}{|l|}{2016} \\
\hline Število kmetijskih gospodarstev & 69.902 & 49.448 & 20.454 \\
\hline Polnovredne delovne moči, PDM & 79.967 & 57.295 & 22.673 \\
\hline Kmetijska zemljišča v uporabi, ha & 479.589 & 342.895 & 136.694 \\
\hline
\end{tabular}




\section{Povprečna velikost in struktura kmetijskih gospodarstev}

Strukturne spremembe $\mathrm{v}$ kmetijstvu v splošnem potekajo v smeri zmanjševanja števila kmetij in povečevanja njihove povprečne velikosti, pogosto merjeno kot velikost kmetijskih površin na kmetijsko gospodarstvo. $\mathrm{V}$ letu 2013 je povprečna velikost kmetij po velikosti kmetijskih površin $\mathrm{v} d r-$ žavah EU-28 znašala 16,1 ha. Največje kmetije po površini obdelovalnih/ kmetijskih površin so na Češkem (133 ha), v Veliki Britaniji (92,3 ha), na Slovaškem (80,7 ha), na Danskem (67,5 ha), v Luksemburgu (63 ha), v Franciji $(58,7$ ha), v Nemčiji $(58,6$ ha) in v Estoniji $(49,9$ ha). V Sloveniji je bila povprečna velikost 6,7 ha, kar je daleč pod povprečjem za EU-28 in Slovenijo uvršča na 25. mesto. Manjša povprečna velikost kmetij je na Cipru (3,1 ha), Malti (1,2 ha) in v Romuniji (3,6 ha) (Eurostat 2017).

Razlike v velikosti kmetij so tudi znotraj posameznih držav po regijah, posebej pri večjih državah $\mathrm{z}$ določenimi razlikami v zgodovinsko-institucionalnem razvoju, kot to na primer velja med nekdanjo vzhodno in zahodno Nemčijo, saj je povprečna velikost kmetij glede na število hektarjev kmetijske zemlje v uporabi na kmetijo na območju nekdanje vzhodne Nemčije precej večja kot $\mathrm{v}$ zahodni Nemčiji. Različna povprečna velikost kmetij je lahko povezana tudi z različno organizacijsko obliko kmetij, kjer praviloma velja, da so družinske kmetije $\mathrm{v}$ zahodni Nemčiji v povprečju precej manjše velikosti kot korporativna podjetja, ki so pomembno zastopana v kmetijski strukturi na ozemlju nekdanje vzhodne Nemčije.

Poleg same povprečne fizične in ekonomske velikosti kmetij je pomembna porazdelitev $\mathrm{v}$ velikostni strukturi kmetij. Glede na fizično velikost kmetij v primeru kmetijske zemlje spada Slovenija v skupino držav z velikim deležem kmetij, ki so manjše od 5 ha kmetijske zemlje $v$ uporabi, in $\mathrm{z}$ relativno majhnim deležem kmetij $\mathrm{z}$ več kot 100 ha kmetijske zemlje v uporabi. Gre za t. i. bimodalno velikostno strukturo kmetij, ki je podobna tudi $\mathrm{v}$ nekaterih drugih tranzicijskih srednje- in vzhodnoevropskih državah (Bolgarija, Hrvaška, Latvija, Litva, Madžarska, Poljska, Romunija in Slovaška) in v mediteranskih državah (Grčija, Ciper, Malta, Portugalska ter delno Italija in Španija). V nekaterih mediteranskih državah so zato posebej razvite različne oblike združenja proizvajalcev in zadruge, s pomočjo katerih poskušajo odpraviti pomanjkljivosti majhnosti kmetij in povečati ekonomije obsega, ki jih pogosto zahtevajo vertikalno povezani ponudbeni kanali, ki so pod posebno močnim vplivom velikih trgovskih verig. 
Tabela 4.3: Število kmetijskih gospodarstev in površina kmetijske zemlje v uporabi po velikostnih razredih v Sloveniji

\begin{tabular}{|c|c|c|c|c|c|c|c|}
\hline & 2000 & 2003 & 2005 & 2007 & 2010 & 2013 & 2016 \\
\hline \multicolumn{8}{|c|}{ Število kmetijskih gospodarstev } \\
\hline SKUPAJ & 86.467 & 77.149 & 77.175 & $75 \cdot 340$ & 74.646 & 72.377 & 69.902 \\
\hline brez KZU & 44 & 23 & 34 & 43 & 191 & 100 & 83 \\
\hline več kot o do pod o,5 ha & 3.307 & 2.198 & 2.682 & 2.956 & 3.969 & 2.475 & 2.888 \\
\hline 0,5 do pod 1 ha & 4.692 & 3.177 & 3.049 & 4.011 & 4.061 & 3.970 & 2.708 \\
\hline 1 do pod 2 ha & 14.999 & 11.894 & 12.210 & 11.617 & 12.372 & 12.109 & 11.904 \\
\hline 2 do pod 3 ha & 12.256 & 10.326 & 10.996 & 10.496 & 10.201 & 10.551 & 10.485 \\
\hline 3 do pod 5 ha & 18.130 & 16.777 & 16.868 & 15354 & 14.934 & 14.579 & 13.851 \\
\hline 5 do pod 10 ha & 22.058 & 20.633 & 19.775 & 19.143 & 17.530 & 17.207 & 16.174 \\
\hline 10 do pod 15 ha & 6.928 & 7.049 & 6.386 & 5.897 & 5.784 & 5.489 & 5.415 \\
\hline 15 do pod 20 ha & 2.237 & 2.646 & 2.433 & 2.652 & 2.316 & 2.393 & 2.507 \\
\hline 20 do pod 30 ha & 1.264 & 1.648 & 1.709 & 1.895 & 1.916 & 1.956 & 2.100 \\
\hline 30 do pod 50 ha & 377 & 555 & 723 & 888 & 920 & 1.043 & 1.195 \\
\hline 50 do pod 100 ha & 101 & 149 & 210 & 290 & 358 & 394 & 480 \\
\hline 100 ha ali več & 74 & 75 & 101 & 98 & 94 & 112 & 113 \\
\hline \multicolumn{8}{|c|}{ Površina (ha) } \\
\hline SKUPAJ & 485.879 & 486.473 & 485.432 & 488.774 & 474.432 & 477.023 & 479.589 \\
\hline brez KZU & $\mathrm{O}$ & o & o & o & o & o & o \\
\hline več kot o do pod o,5 ha & 1023 & 684 & 782 & 801 & 1136 & 679 & 776 \\
\hline 0,5 do pod 1 ha & 3.444 & 2.365 & 2.255 & 2.986 & 2.925 & 2.864 & 1.954 \\
\hline 1 do pod 2 ha & 21.932 & 17.690 & 17.746 & 16.970 & 17.989 & 17.456 & 17.054 \\
\hline 2 do pod 3 ha & 30.237 & 25.403 & 26.921 & 25.769 & 24.985 & 25.889 & 25.643 \\
\hline 3 do pod 5 ha & 70.875 & 65.713 & 66.151 & 60.145 & 58.127 & 56.284 & 52.891 \\
\hline 5 do pod 10 ha & 155.278 & 145.170 & 139.239 & 134.180 & 122.842 & 120.317 & 113.081 \\
\hline 10 do pod 15 ha & 82.872 & 85.031 & 76.638 & 71.078 & 69.650 & 66.154 & 64.634 \\
\hline 15 do pod 20 ha & 38.191 & 45.230 & 41.504 & 45.387 & 39.841 & 40.850 & 42.864 \\
\hline 20 do pod 30 ha & 29.927 & 39.233 & 40.452 & 45.228 & 45.939 & $47 \cdot 318$ & 50.454 \\
\hline 30 do pod 50 ha & 13.805 & 20.660 & 26.345 & 32.945 & 34.250 & 38.955 & 45.169 \\
\hline 50 do pod 100 ha & 6.361 & 9.647 & 13.841 & 19.266 & 23.978 & 26.339 & 31.710 \\
\hline 100 ha ali več & 31.933 & 29.647 & 33.558 & 34.021 & 32.772 & 33.919 & 33.359 \\
\hline
\end{tabular}

\section{Vir: SURS 2017.}


Tabela 4.3 potrjuje zmanjšanje števila kmetijskih gospodarstev $\mathrm{v}$ Sloveniji in spremembe $\mathrm{v}$ velikostni strukturi kmetijske površine $\mathrm{v}$ uporabi na kmetijsko gospodarstvo. Zmanjšano število je opazno za majhna kmetijska gospodarstva (brez kmetijske zemlje in $\mathrm{v}$ velikosti do treh hektarjev) in posebej za srednje velika kmetijska gospodarstva med 3 in 10 ha kmetijske zemlje $\mathrm{v}$ uporabi ter tudi med 10 in 15 ha površine kmetijske zemlje v uporabi. Povečanje števila je opazno za kmetijska gospodarstva, ki so večja od 15 ha kmetijske površine v uporabi.

Spremembe so še opaznejše v površinah kmetijske zemlje v uporabi, ki jo obdeluje posamezna velikostna struktura kmetijskih gospodarstev. Zmanjšanje kmetijskih površin $\mathrm{v}$ uporabi je za kmetijska gospodarstva $\mathrm{v}$ velikosti do vključno 15 ha in povečanje velja za velikostne skupine nad 15 ha. Posebej viden je upad kmetijskih površin v uporabi za srednje velikostne razrede kmetijskih gospodarstev med 3 in 10 ha kakor tudi za velikosti do 15 ha kmetijske zemlje $\mathrm{v}$ uporabi na kmetijsko gospodarstvo. Največji porast kmetijskih površin $\mathrm{v}$ uporabi je za velikostne razrede kmetijskih gospodarstev med 20 in 100 ha, kakor tudi med 15 in 20 ha in delno nad 100 ha.

Po ekonomski velikosti se število kmetijskih gospodarstev v Sloveniji zmanjšuje zaradi zmanjševanja števila kmetijskih gospodarstev, ki so manjša od 4.000 evrov (tabela 4.4). Na drugi strani se število kmetijskih gospodarstev posebej povečuje za velikostni razred nad 25.000 evrov. $\mathrm{Z}$ izjemo dveh najmanjših velikostnih razredov manj kot $4.000 \mathrm{ev}-$ rov se ekonomska velikost kmetijskih gospodarstev povečuje. Nadalje se - z izjemo kmetijskih gospodarstev, večjih od 50.000 evrov - kmetijska zemljišča $\mathrm{v}$ uporabi zmanjšujejo. Poleg opuščanja obdelave in zaraščanja kmetijskih zemljišč so lahko razlogi za zmanjševanje kmetijskih zemljišč $\mathrm{v}$ uporabi tudi drugi, na primer širjenje mest in vasi na nekdanja kmetijska zemljišča, izgradnja cestne (na primer avtocestni križ) in druge infrastrukture. Podobno kot pri kmetijskih zemljiščih v uporabi se $-\mathrm{z}$ izjemo kmetijskih gospodarstev, večjih od 50.000 evrov - število glav velike živine zmanjšuje.

Zmanjševanje PDM na kmetijskih gospodarstvih ni linearno. Med letoma 2007 in 2010 je opazno zmanjšanje PDM za ekonomske velikostne razrede kmetijskih gospodarstev do 25.000 evrov. Med letoma 2010 in 2013 je $-\mathrm{z}$ izjemo ekonomskih velikostnih razredov do 4.000 evrov in delno za velikostni razred med 8.000 in 15.000 evrov - za druge ekonomske ve- 
likostne razrede opazno povečanje PDM na kmetijskih gospodarstvih v Sloveniji.

Tabela 4.4: Kmetijska gospodarstva po ekonomskih razredih velikosti

\begin{tabular}{|c|c|c|c|c|c|}
\hline $\begin{array}{c}\text { Velikostni } \\
\text { razred } \\
\text { ekonomske } \\
\text { velikosti }\end{array}$ & $\begin{array}{c}\text { Število } \\
\text { kmetijskih } \\
\text { gospodarstev }\end{array}$ & $\begin{array}{c}\text { Ekonomska } \\
\text { velikost } \\
\text { (v 1.00o EUR) }\end{array}$ & $\begin{array}{l}\text { Kmetijska } \\
\text { zemljišča v } \\
\text { uporabi (v ha) }\end{array}$ & $\begin{array}{c}\text { Število glav } \\
\text { velike Živine } \\
(G V Z ̌)\end{array}$ & $\begin{array}{l}\text { Polnovredne } \\
\text { delovne moči } \\
\text { (PDM) }\end{array}$ \\
\hline \multicolumn{6}{|l|}{2007} \\
\hline Skupaj & $75 \cdot 340$ & 884.996 & 488.774 & $433 \cdot 382$ & 83.950 \\
\hline $\begin{array}{l}\text { manj kot } 2.000 \\
\text { EUR }\end{array}$ & 16.969 & 20.279 & 27.704 & 5.706 & 9.397 \\
\hline $\begin{array}{l}\text { od } 2.000 \text { do } \\
\text { manj kot } 4.000 \\
\text { EUR }\end{array}$ & 16.851 & 48.903 & 51220 & 22.268 & 13.785 \\
\hline $\begin{array}{l}\text { od } 4.000 \text { do } \\
\text { manj kot } 8.000 \\
\text { EUR }\end{array}$ & 18.447 & 105.721 & 94141 & 60.715 & 20.480 \\
\hline $\begin{array}{l}\text { od } 8.000 \text { do } \\
\text { manj kot } \\
15.000 \text { EUR }\end{array}$ & 11.051 & 119.612 & 85811 & 72.987 & $15 \cdot 383$ \\
\hline $\begin{array}{l}\text { od } 15.000 \\
\text { do manj kot } \\
25.000 \text { EUR }\end{array}$ & $5 \cdot 366$ & 102.859 & 61964 & 59.866 & 9.088 \\
\hline $\begin{array}{l}\text { od } 25.000 \\
\text { do manj kot } \\
50.000 \text { EUR }\end{array}$ & 4.296 & 149.911 & 73064 & 84.284 & 8.182 \\
\hline $\begin{array}{l}\text { od } 50.000 \\
\text { do manj kot } \\
100.000 \text { EUR }\end{array}$ & 1.634 & 109.404 & 46909 & 59.230 & 3.854 \\
\hline $\begin{array}{l}\text { 100.0oo EUR } \\
\text { ali več }\end{array}$ & 724 & 228.306 & 47961 & 68.328 & 3.783 \\
\hline 2010 & & & & & \\
\hline Skupaj & 74.646 & 913.194 & 474.432 & 421.553 & 77.012 \\
\hline $\begin{array}{l}\text { manj kot } 2.000 \\
\text { EUR }\end{array}$ & 15.691 & 18.970 & 22.942 & 5.112 & 7.404 \\
\hline $\begin{array}{l}\text { od } 2.000 \text { do } \\
\text { manj kot } 4.000 \\
\text { EUR }\end{array}$ & 17.650 & 51.757 & 49.103 & 21.538 & 127.53 \\
\hline $\begin{array}{l}\text { od } 4.000 \text { do } \\
\text { manj kot } 8.000 \\
\text { EUR }\end{array}$ & 18.120 & 103.055 & 85.235 & 55.140 & 17.593 \\
\hline $\begin{array}{l}\text { od } 8.000 \text { do } \\
\text { manj kot } \\
15.000 \text { EUR }\end{array}$ & 10.648 & 114.507 & 80.072 & 66.241 & 13.193 \\
\hline $\begin{array}{l}\text { od } 15.000 \\
\text { do manj kot } \\
25.000 \text { EUR }\end{array}$ & 4.996 & 96.202 & 53.654 & 51.188 & 7.634 \\
\hline
\end{tabular}




\begin{tabular}{|c|c|c|c|c|c|}
\hline $\begin{array}{l}\text { Velikostni } \\
\text { razred } \\
\text { ekonomske } \\
\text { velikosti }\end{array}$ & $\begin{array}{c}\text { Število } \\
\text { kmetijskih } \\
\text { gospodarstev }\end{array}$ & $\begin{array}{c}\text { Ekonomska } \\
\text { velikost } \\
\text { (v 1.00o EUR) }\end{array}$ & $\begin{array}{c}\text { Kmetijska } \\
\text { zemljišča v } \\
\text { uporabi (v ha) }\end{array}$ & $\begin{array}{c}\text { Število glav } \\
\text { velike Živine } \\
\text { (GVŽ) }\end{array}$ & $\begin{array}{l}\text { Polnovredne } \\
\text { delovne moči } \\
\text { (PDM) }\end{array}$ \\
\hline $\begin{array}{l}\text { od } 25.000 \\
\text { do manj kot } \\
50.000 \text { EUR }\end{array}$ & 4463 & 156.163 & 68.502 & 76.792 & 8.337 \\
\hline $\begin{array}{l}\text { od } 50.000 \\
\text { do manj kot } \\
100.000 \text { EUR }\end{array}$ & 2.170 & 147.273 & 54.852 & 70.410 & 4.957 \\
\hline $\begin{array}{l}\text { 100.0oo EUR } \\
\text { ali več }\end{array}$ & 908 & 225.267 & 60.071 & 75.131 & 5.143 \\
\hline 2013 & & & & & \\
\hline Skupaj & 72.377 & 1.009 .230 & 477.023 & 399.349 & 82.746 \\
\hline $\begin{array}{l}\text { manj kot } 2.000 \\
\text { EUR }\end{array}$ & 12.202 & 15.125 & 16.771 & $3 \cdot 371$ & 6.136 \\
\hline $\begin{array}{l}\text { od } 2.000 \text { do } \\
\text { manj kot } 4.000 \\
\text { EUR }\end{array}$ & $15 \cdot 372$ & 44.778 & 37.177 & 14.060 & 11.959 \\
\hline $\begin{array}{l}\text { od } 4.000 \text { do } \\
\text { manj kot } 8.000 \\
\text { EUR }\end{array}$ & 19.284 & 111.052 & 81.659 & 48.531 & 21.153 \\
\hline $\begin{array}{l}\text { od } 8.000 \text { do } \\
\text { manj kot } \\
15.000 \text { EUR }\end{array}$ & 11.434 & 124.360 & 80.731 & 586.93 & $15 \cdot 341$ \\
\hline $\begin{array}{l}\text { od } 15.000 \\
\text { do manj kot } \\
25.000 \text { EUR }\end{array}$ & 5.850 & 111.972 & 61.073 & 50.997 & 8.964 \\
\hline $\begin{array}{l}\text { od } 25.000 \\
\text { do manj kot } \\
50.000 \text { EUR }\end{array}$ & 4.702 & 164.859 & 69.658 & 72.227 & 8.787 \\
\hline $\begin{array}{l}\text { od } 50.000 \\
\text { do manj kot } \\
100.000 \text { EUR }\end{array}$ & 2.408 & 165.489 & 59.598 & 69.779 & $5 \cdot 318$ \\
\hline $\begin{array}{l}\text { 100.ooo EUR } \\
\text { ali več }\end{array}$ & 1.126 & 271.595 & 70.355 & 81.691 & 5.087 \\
\hline
\end{tabular}

Vir: SURS 2017.

\section{Delovna sila v kmetijstvu}

Za delovno silo v kmetijstvu so značilni migracijski tokovi znotraj nacionalnega gospodarstva (industrijske in storitvene dejavnosti), zaradi brezposelnosti in upokojevanja (Bojnec in Dries 2005) ter v tujino. Največ delovne sile, neposredno zaposlene na kmetijah, je na Poljskem (1,9 milijona letnih delovnih ekvivalentov) in v Romuniji (1,6 milijona letnih delovnih ekvivalentov) (Eurostat 2017). Obe omenjeni državi sta novi članici Evropske unije iz srednje in vzhodne Evrope. Med starimi članicami Evropske unije je število letnih delovnih ekvivalentov največje za Italijo (o,82 milijona), 
Španijo (o,81 milijona), Francijo (o,72 milijona), Nemčijo (o,52 milijona) in Grčijo (o,46 milijona). Slovenija je z 82.500 letnih delovnih ekvivalentov na 18. mestu med državami EU-28. Z manj zaposlenimi v kmetijstvu so še Belgija, Danska, Estonija, Ciper, Latvija (za malenkost manj kot Slovenija), Luksemburg, Malta, Slovaška, Finska in Švedska. Ker so nekatere od teh držav po kmetijskih površinah $\mathrm{v}$ uporabi in po številu enot živine precej večje, to kaže, da je slovensko kmetijstvo relativno delovno intenzivnejše in glede na obstoječe strukturne in dane geografske pogoje manj produktivno. Zato ima večjo vlogo pri zaposlovanju $\mathrm{v}$ kmetijstvu in pri poseljenosti na podeželju.

Glede na velikost kmetij, organizacijsko obliko kmetije in na prevladujočo usmeritev v proizvodnji oz. tip kmetovanja se praviloma razlikuje tudi vrsta delovne sile, ki je angažirana pri delu v kmetijstvu. Več kot tri četrtine delovne sile v kmetijstvu v državah EU-28 predstavlja lastno delo družine na kmetiji. Temu sledi redna zaposlitev dela nedružinskih članov (več kot $15 \%$ ) in neredna zaposlitev nedružinskih članov (okrog $8 \%$ ) (Eurostat 2017). Ob Poljski je Slovenija na vrhu držav EU-28, kjer večino delovne sile v kmetijstvu predstavlja lastna delovna sile družine na kmetiji. Podobno velja tudi za druge države EU-28, ki imajo manjšo velikostno sestavo kmetij, na primer Hrvaška, Irska, Romunija, Malta in Grčija. Na drugi strani so države EU-28 z največjimi kmetijami oz. kmetijskimi podjetji in podobnimi organizacijami, ki v večji meri uporabljajo redno zaposleno nedružinsko delovno silo, na primer Češka, Slovaška, Francija in Estonija. Delež neredno zaposlene nedružinske delovne sile v nobeni od držav EU-28 ne presega $20 \%$ in je med največjimi v Španiji, na Nizozemskem in v Italiji. Pomembno vlogo pri tem igrajo sezonska dela v času setve in žetve ter druga občasna priložnostna dela, ki so poznana tudi v slovenskem kmetijstvu.

V Sloveniji se vložek dela na kmetijskih gospodarstvih, izražen v PDM, zmanjšuje zlasti zaradi zmanjševanja družinske delovne sile, in sicer gospodarjev-upraviteljev in drugih članov gospodinjstev, ki živijo na družinski kmetiji (tabela 4.5). Zmanjšujejo se tudi število redno zaposlenih v kmetijskih podjetjih in zadrugah ter strojne storitve na družinskih kmetijah. Ciklično tendenčno zmanjševanje je opazno za sezonsko in priložnostno delo na družinskih kmetijah. Povečano število, ki pa je med manjšimi v velikostni strukturi, je opazno za redno zaposlene na družinskih kmetijah, za sezonsko in priložnostno delo $\mathrm{v}$ kmetijskih podjetjih in zadrugah ter za strojne storitve $\mathrm{v}$ kmetijskih podjetjih in zadrugah. 
Tabela 4.5: Vložek dela na kmetijskih gospodarstvih (v PDM) po izvoru delovne sile v Sloveniji

\begin{tabular}{|c|c|c|c|c|c|c|c|}
\hline & 2000 & 2003 & 2005 & 2007 & 2010 & 2013 & 2016 \\
\hline Izvor delovne sile - skupaj & 107.809 & 95.605 & 95.263 & 83.950 & 77.012 & 82.746 & 79.967 \\
\hline $\begin{array}{l}\text { Družinska delovna sila } \\
\text { - gospodar-upravitelj }\end{array}$ & 44.690 & 38.763 & 40.912 & 36.816 & 34.645 & 38.866 & 36.609 \\
\hline $\begin{array}{l}\text { Družinska delovna sila } \\
\text { - drugi člani gospodinj- } \\
\text { stev, ki živijo na družinski } \\
\text { kmetiji }\end{array}$ & 55.028 & 48.978 & 45.846 & 40.581 & 34.037 & 38.420 & 36.978 \\
\hline $\begin{array}{l}\text { Redno zaposleni } \\
\text { - na družinskih kmetijah }\end{array}$ & 156 & 167 & 221 & 175 & 225 & 246 & 359 \\
\hline $\begin{array}{l}\text { Redno zaposleni } \\
\text { - v kmetijskih podjetjih in } \\
\text { zadrugah }\end{array}$ & 4.032 & 3.104 & 3.124 & 2.445 & 2.610 & 1.942 & 2.078 \\
\hline $\begin{array}{l}\text { Sezonsko in priložnostno } \\
\text { delo } \\
\text { - na družinskih kmetijah }\end{array}$ & 3.622 & 4.081 & 4.558 & 3.253 & 4.686 & 2.658 & 3.255 \\
\hline $\begin{array}{l}\text { Sezonsko in priložnostno } \\
\text { delo - v kmetijskih } \\
\text { podjetjih in zadrugah }\end{array}$ & $\cdots$ & 273 & 315 & 449 & 573 & 389 & 494 \\
\hline $\begin{array}{l}\text { Strojne storitve - na } \\
\text { družinskih kmetijah }\end{array}$ & 281 & 233 & 277 & 222 & 227 & 210 & 177 \\
\hline $\begin{array}{l}\text { Strojne storitve - v kmetij- } \\
\text { skih podjetjih in zadrugah }\end{array}$ & $\ldots$ & 6 & 10 & 9 & 10 & 15 & 17 \\
\hline
\end{tabular}

\section{Vir: SURS 2017.}

Primerjava tabel 4.5 in 4.6 pokaže razlike v vložku dela na kmetijskih gospodarstvih, ki je izraženo v PDM in v številu oseb. Večje število oseb glede na PDM kaže na to, da je sodelujoče število oseb pri delih na kmetijskih gospodarstvih večje, kot če se delo izrazi v PDM, kar pomeni, da številni med njimi niso polno zaposleni v kmetijstvu in na kmetijskem gospodarstvu. Splošne tendence in struktura števila oseb glede vloženega dela na kmetijskih gospodarstvih (tabela 4.6) pa ostajajo podobne kot pri PDM (tabela 4.5). Večina vloženega dela na kmetijskih gospodarstvih v Sloveniji je družinska delovna sila, in sicer gospodar oz. upravitelj ter drugi člani gospodinjstev, ki živijo na družinski kmetiji. Delež družinske delovne sile (ene in druge) se zmanjšuje. Nova tendenca je porast redno zaposlenih na družinskih kmetijah in povečana pomembnost sezonskega ter priložnostnega dela v kmetijskih podjetjih in zadrugah. Na drugi strani pa se zmanjšuje število oseb, ki so redno zaposlene v kmetijskih podjetjih in zadrugah. 
Tabela 4.6: Vložek dela na kmetijskih gospodarstvih v PDM po izvoru delovne sile (število oseb)

\begin{tabular}{|c|c|c|c|c|c|c|c|}
\hline & 2000 & 2003 & 2005 & 2007 & 2010 & 2013 & 2016 \\
\hline $\begin{array}{l}\text { Družinska delovna sila } \\
\text { - gospodar-upravitelj }\end{array}$ & 86.336 & 77.037 & 77.042 & 75.209 & 74.425 & 72.176 & 69.671 \\
\hline $\begin{array}{l}\text { Družinska delovna sila } \\
\text { - drugi člani gospo- } \\
\text { dinjstev, ki živijo na } \\
\text { družinski kmetiji }\end{array}$ & 166.192 & 130.706 & 126.975 & 122.286 & 130.820 & 125.822 & 123.498 \\
\hline $\begin{array}{l}\text { Redno zaposleni - na } \\
\text { družinskih kmetijah }\end{array}$ & 197 & 268 & 283 & 247 & 352 & 354 & 544 \\
\hline $\begin{array}{l}\text { Redno zaposleni - v } \\
\text { kmetijskih podjetjih in } \\
\text { zadrugah }\end{array}$ & 4.058 & 3.234 & 3.271 & 2.853 & 2.896 & 2.279 & 2.322 \\
\hline $\begin{array}{l}\text { Sezonsko in priložno- } \\
\text { stno delo - na družin- } \\
\text { skih kmetijah }\end{array}$ & - & - & - & - & - & - & - \\
\hline $\begin{array}{l}\text { Sezonsko in priložno- } \\
\text { stno delo - v kmetijskih } \\
\text { podjetjih in zadrugah }\end{array}$ & $\cdots$ & 998 & 1.195 & 1.664 & 2.698 & 2.987 & 3.036 \\
\hline $\begin{array}{l}\text { Strojne storitve - na } \\
\text { družinskih kmetijah }\end{array}$ & - & - & - & - & - & - & - \\
\hline $\begin{array}{l}\text { Strojne storitve }-\mathrm{v} \\
\text { kmetijskih podjetjih in } \\
\text { zadrugah }\end{array}$ & - & - & - & - & - & - & - \\
\hline
\end{tabular}

\section{Vir: SURS 2017.}

Družinska delovna sila - gospodar-upravitelj in drugi družinski člani - se zmanjšuje po spolu in po dveh kohezijski regijah v Sloveniji (tabela 4.7). Povprečna starost gospodarja-upravitelja je na podobni ravni, ki je 57 let. Ta je podobna ali nekoliko nižja v vzhodni kot $\mathrm{v}$ zahodni slovenski kohezijski regiji. Povprečna starost moških gospodarjev-upraviteljev je nekoliko nižja kot žensk, kar velja za vzhodno in zahodno kohezijsko regijo. Drugi družinski člani so v povprečju mlajši kot gospodarji-upravitelji. Število drugih družinskih članov se je zmanjšalo in njihova povprečna starost se je zvišala, zlasti v zadnjih letih. Število drugih družinskih članov se je bolj zmanjšalo $\mathrm{v}$ vzhodni kot pa $\mathrm{v}$ zahodni kohezijski regiji. Povprečna starost drugih družinskih članov je podobna med vzhodno in zahodno kohezijsko regijo. Kljub povečanju povprečne starosti moških - drugih družinskih članov ostaja ta precej nižja kot pri ženskah, katerih povprečna starost se prav tako povišuje. Gibanja v povprečni starosti drugih družinskih članov so podobna za vzhodno in zahodno kohezijsko regijo. Razlike so v 
Tabela 4.7: Delovno aktivni družinski člani na družinski kmetiji po spolu in kohezijski regiji $v$ Sloveniji

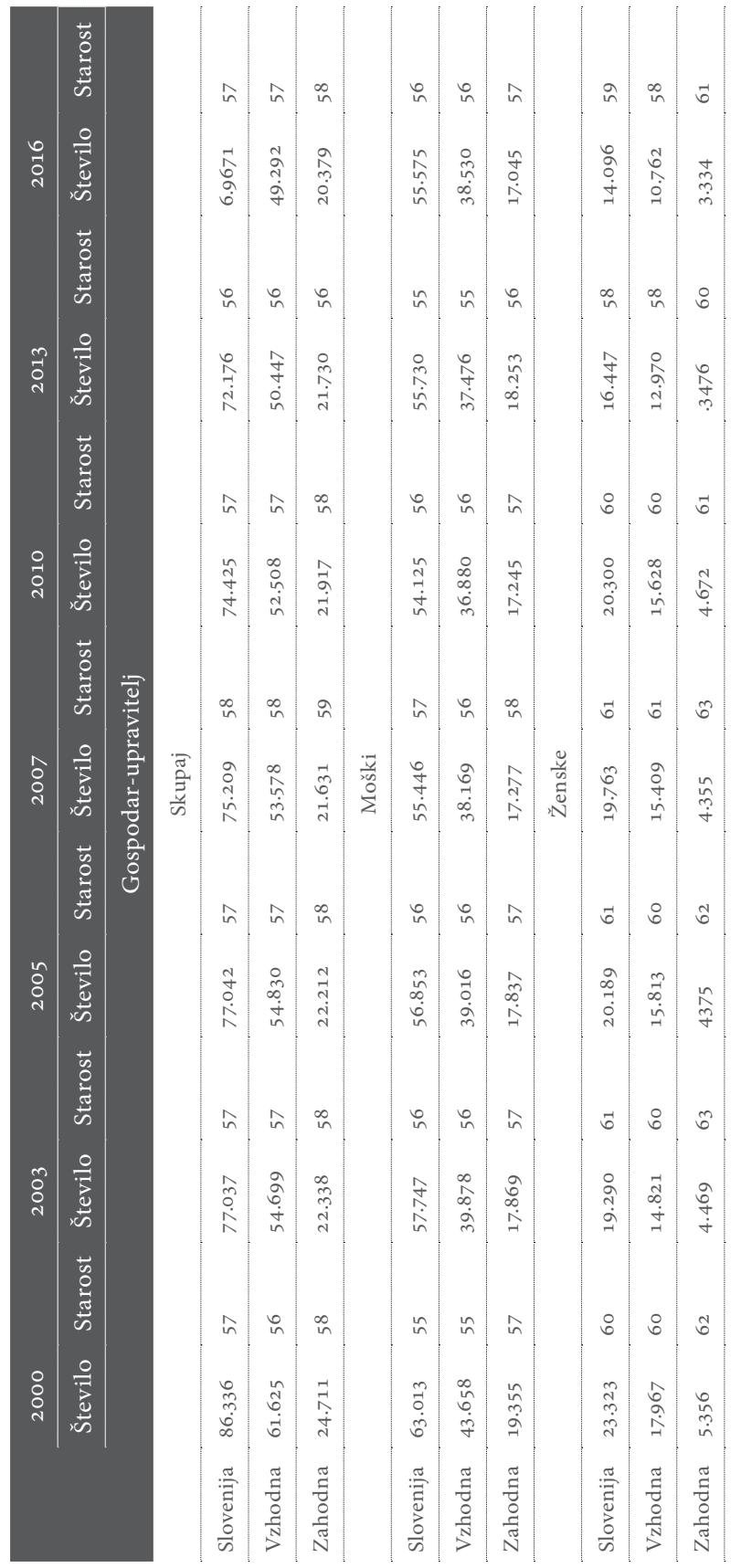


4: INTEGRIRANJE DOHODKOV V SODOBNI KMEČKI EKONOMIJI

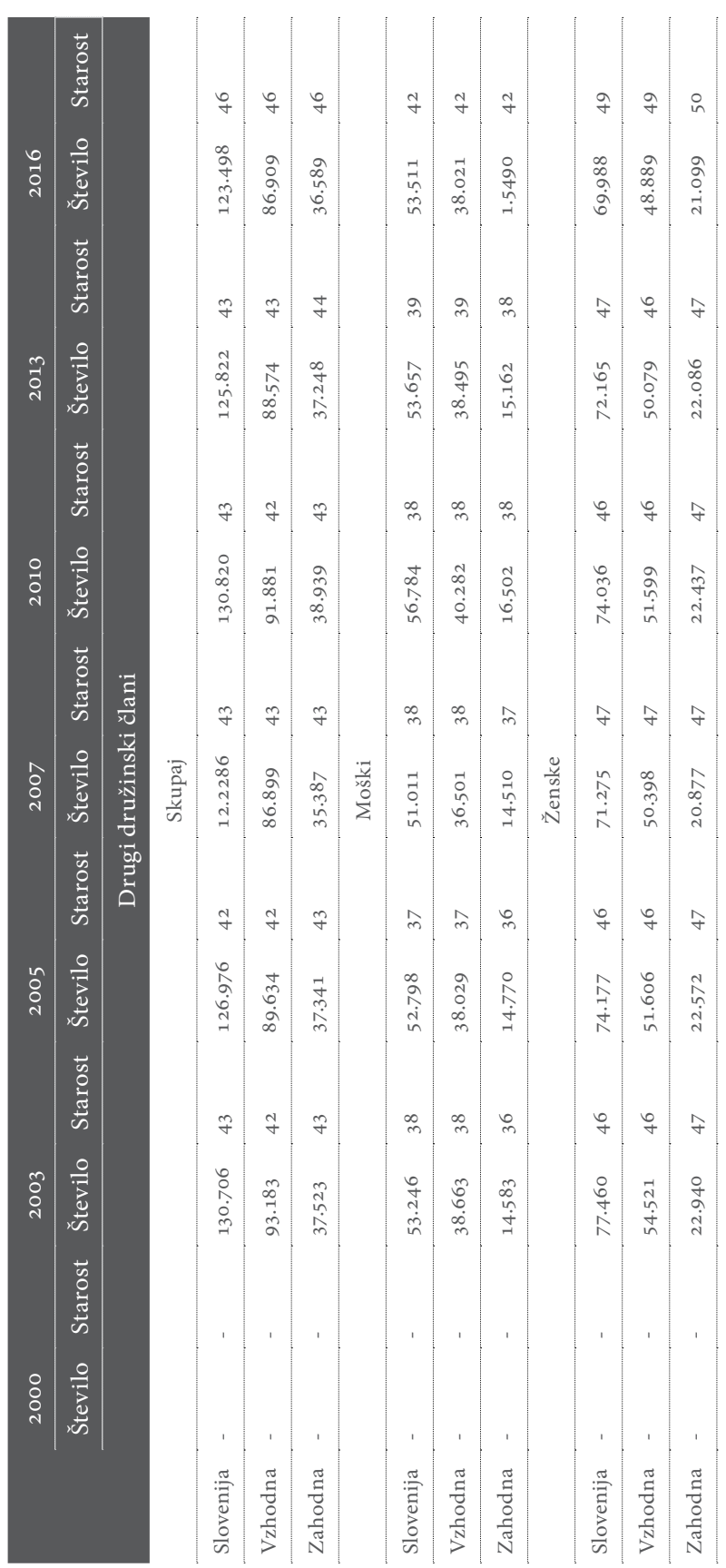

Opomba: Število oseb in povprečna starost Vir: SURS 2017. 
gibanju števila drugih družinski članov. V vzhodni kohezijski regiji se je število moških zmanjšalo, medtem ko se je $\mathrm{v}$ zahodni kohezijski regiji povečalo. Število žensk kot drugih družinskih članov se je zmanjšalo v vzhodni in zahodni kohezijski regiji.

\section{Spreminjanje kmetijskih zemljišč v uporabi}

Celotna velikost kmetijske zemlje v uporabi je odvisna od velikosti države in njenih geografsko-klimatskih značilnosti. Med državami EU-28 je največ zemlje v uporabi v Franciji (27,7 milijona ha), v Španiji (23,3 milijona ha), v Veliki Britaniji (17,1 milijona ha), v Nemčiji (16,7 milijona ha), na Poljskem $(14,4$ milijona ha), v Romuniji (13,1 milijona ha) in v Italiji (12,1 milijona ha). Slovenija se uvršča na 25. mesto (Eurostat 2017). Za njo so le Luksemburg, Ciper in Malta.

Kot je razvidno iz tabele 4.8 , se kmetijska zemljišča v uporabi v Sloveniji iz leta $\mathrm{v}$ leto spreminjajo $\mathrm{s}$ tendenco njihovega zmanjševanja. To velja tako za prevladujoče družinske kmetije kot tudi za kmetijska podjetja.

Tabela 4.8: Kmetijska zemljišča v uporabi v Sloveniji (v ha)

\begin{tabular}{lccccccc} 
& 2000 & 2003 & 2005 & 2007 & 2010 & 2013 & 2016 \\
$\begin{array}{lccccc}\text { Kmetijska } \\
\text { gospodarstva }\end{array}$ & 485.879 & 486.473 & 485.432 & 488.774 & 474.432 & 477.023 & 479.589 \\
\hline $\begin{array}{l}. . \text { Kmetijska } \\
\text { podjetja }\end{array}$ & 29.664 & 26.895 & 25.447 & 25.593 & 26.581 & 26.077 & 25.528 \\
\hline \begin{tabular}{l}
..Družinske kmetije \\
\hline
\end{tabular} & 456.215 & 459.578 & 459.986 & 463.182 & 447.851 & 450.946 & 454.060 \\
\hline
\end{tabular}

\section{Vir: SURS 2017.}

\section{Spreminjanje števila živine in kmetijska gospodarstva z živino}

Med državami EU-28 je največ enot živine v Franciji (21,9 milijona), v Nemčiji (18,4 milijona), v Španiji (14,5 milijona), v Veliki Britaniji (13,3 milijona), v Italiji (9,4 milijona), na Poljskem (9,2 milijona), na Nizozemskem (6,6 milijona) in na Irskem (5,9 milijona). Slovenija je s 488 tisoč enotami živine na 23. mestu. Za njo so Estonija, Ciper, Luksemburg, Malta in z nekoliko manjšim številom živine kot Slovenija tudi Latvija (Eurostat 2017).

Podobno kot se je razrahljala tradicionalna povezanost med družinskim lastništvom kmetijske zemlje in njeno obdelavo $\mathrm{z}$ lastnim delom na 
družinski kmetiji, se je zmanjšal tudi delež reje živine na družinskih kmetijah. V letu 2016 se je v Sloveniji z živinorejo ukvarjalo okrog 80 \% kmetijskih gospodarstev: okrog $54 \%$ kmetijskih gospodarstev je redilo perutnino, $47 \%$ govedo, $32 \%$ prašiče, $9 \%$ ovce, $8 \%$ konje in $7 \%$ koze. Zanimivo je, da se je število kmečkih gospodarstev s kravami zmanjšalo bolj - v letu 2016 je le nekaj več kot 35 \% kmetijskih gospodarstev - kot to velja za govedo (SURS 2017).

Tabela 4.9: Število kmetijskih gospodarstev in število živine po kohezijskih regijah v Sloveniji

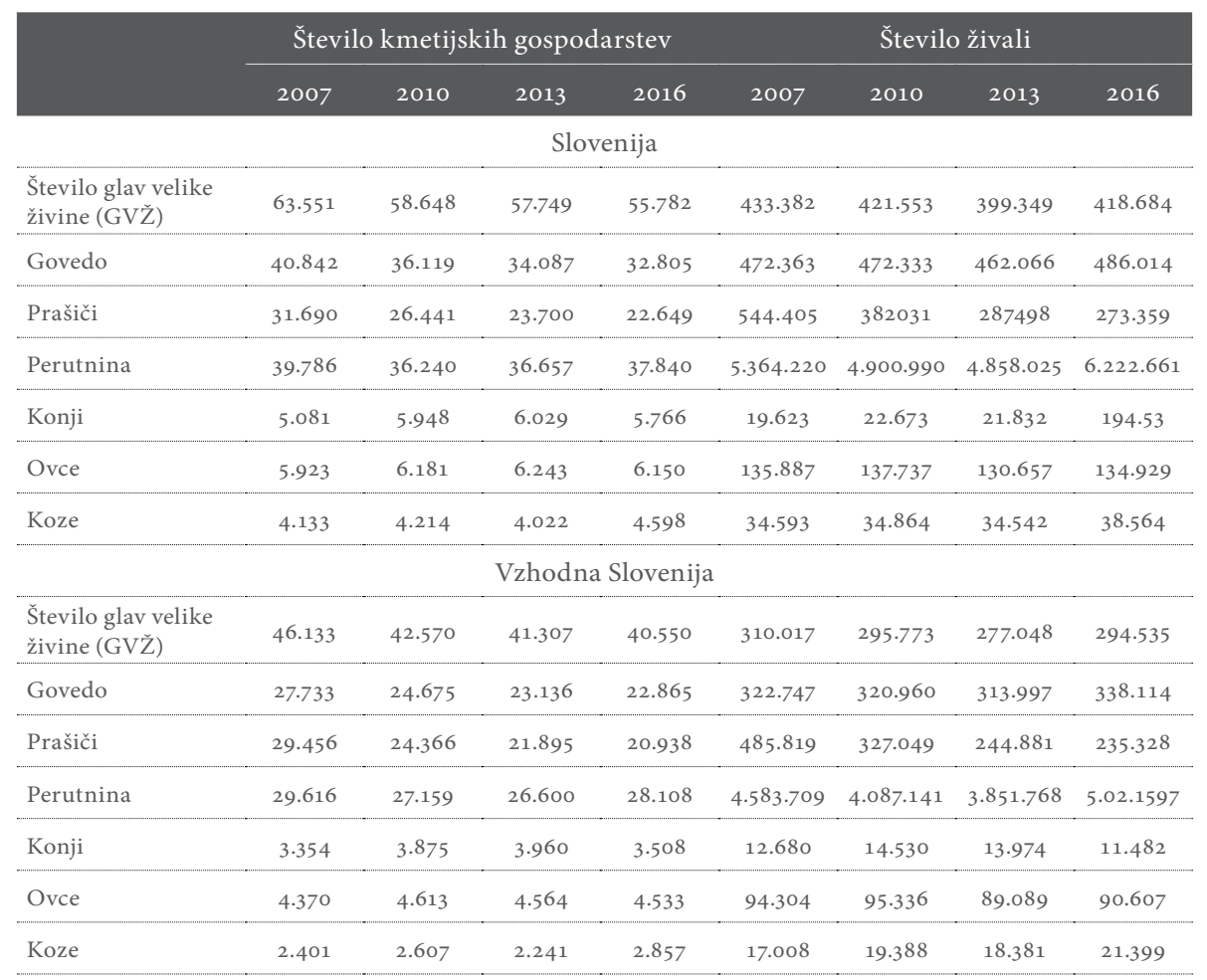




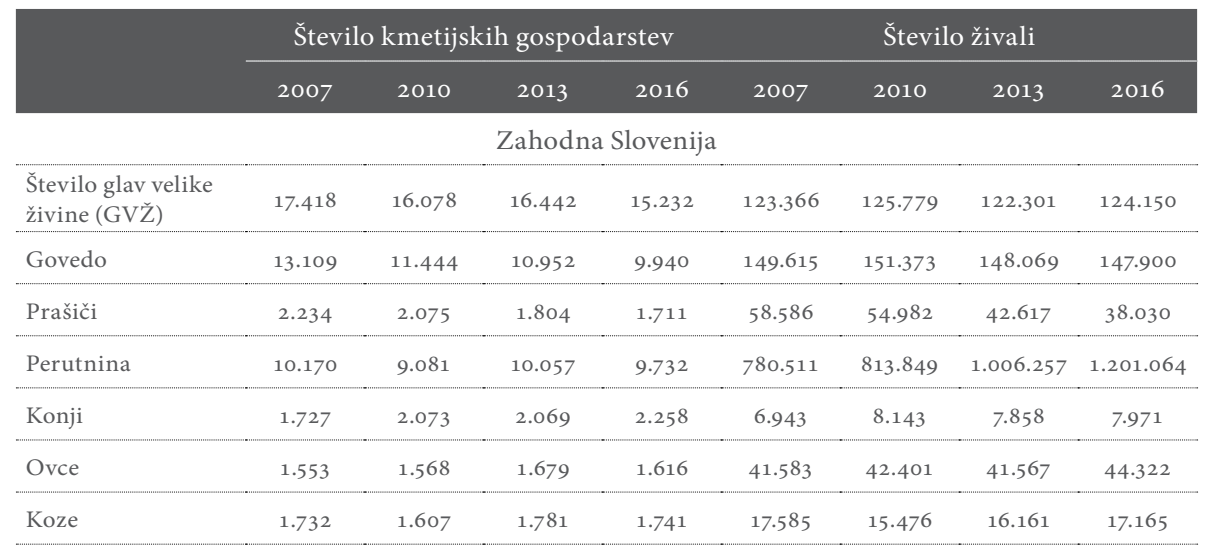

\section{Vir: SURS 2017.}

Medtem ko se število kmetijskih gospodarstev in število glav velike živine zmanjšuje, obstajajo razlike v spreminjanju strukture živine (tabela 4.9). Padec števila kmetijskih gospodarstev in števila živine je zlasti opazen pri prašičih, pri kozah pa je opazen porast. Pri govedu in perutnini se je zmanjšalo število gospodarstev in povečalo število živali. Pri konjih in ovcah se je povečalo število gospodarstev in delno zmanjšalo število živali. Večji del slovenske živinoreje je v vzhodni kohezijski regiji v Sloveniji, kjer so smeri razvoja števila kmetijskih gospodarstev in števila živali dokaj podobne strukturi in gibanjem, ki veljajo za celotno Slovenijo. $\mathrm{Z}$ manjšimi izjemami so strukture živali in njihove tendence podobne tudi $v$ slovenski zahodni kohezijski regiji. Med izjemami v tej regiji je zmanjšanje števila goveda in povečanje števila konj in ovc.

Posebej zanimiv je primer števila krav molznic in njihovega števila na kmečko gospodarstvo. Krave molznice so imele včasih na slovenskih družinskih kmetijah pomembno vlogo kot vir doma pridelane hrane za kmečko gospodarstvo (mleko in pozneje meso telet oz. goveda), kot vir denarnega dohodka od prodaje mleka in goveda prek tržnih kanalov ter kot pomoč pri določenih fizičnih delih na kmetiji. Če je v preteklosti veljalo pravilo, da ima slovenska družinska kmetija vsaj eno kravo za prehrano z mlekom in morebitno pomoč pri delu, kot je bilo na primer oranje pred uvedbo traktorjev in sodobne kmetijske mehanizacije, je sodoben razvoj šel v smeri, da je večina kmetijskih gospodarstev opustila rejo krav molznic in lastno proizvodnjo mleka. Na primer, v letu 2000 je imelo krave molznice 28.588 kmečkih gospodarstev, medtem ko jih je bilo v letu 2016 
le še 9.572 (tabela 4.10). Največji upad kmečkih gospodarstev pri reji krav molznic je za manjše črede, posebno $\mathrm{z}$ eno do dvema kravama, sledijo črede s tremi do štirimi kravami, s petimi do devetimi kravami in $\mathrm{z}$ desetimi do štirinajstimi kravami. Število kmečkih gospodarstev s petnajstimi ali več kravami pa se je povečalo. To kaže na občutne strukturne spremembe $\mathrm{v}$ tradicionalni kmečki ekonomiji, ki je bila ne glede na velikost kmetije močno vezana na pridelavo mleka. Zaradi uvedbe zahtevnejših in zaostrenejših standardov kakovosti pri odkupu in prodaji mleka ter mlečnih izdelkih je postala reja mleka na manjših kmetijah nekonkurenčna, kar je posledično vodilo $\mathrm{v}$ opuščanje reje krav molznic na manjših kmetijah in $\mathrm{v}$ občutno zmanjšanje števila kmetijskih gospodarstev s kravami molznicami. Na drugi strani pa je bilo opazno povečanje koncentracije $\mathrm{z}$ večjim številom krav molznic na manjšem številu kmečkih gospodarstev, njihova specializacija in komercializacija $\mathrm{v}$ mlečno proizvodnjo na večjih kmetijah. Prelom med zmanjševanjem in povečevanjem števila gospodarstev pri reji krav molznic nastopi pri 15 kravah, kar vodi do popolnoma nove strukture $\mathrm{v}$ reji krav molznic in prodaji mleka s slovenskih kmetij.

Tabela 4.IO: Število kmetijskih gospodarstev in velikostni razredi števila krav molznic v Sloveniji

\begin{tabular}{lccccccc}
$\begin{array}{c}\text { Velikstni } \\
\text { razred krav } \\
\text { molznic }\end{array}$ & 2000 & 2003 & 2005 & 2007 & 2010 & 2013 & 2016 \\
\hline SKUPAJ & 28.588 & 17.189 & 19.711 & 19.196 & 10.953 & 9.770 & 9.572 \\
\hline $1-2$ & 12.970 & 4.759 & 7.927 & 8.044 & 3.454 & 3.037 & 2.842 \\
\hline $3-4$ & 5.906 & 3.361 & 3.457 & 3.535 & 1.298 & 1.028 & 1.144 \\
\hline $5-9$ & 5.973 & 4.709 & 4.256 & 3.702 & 2.412 & 2.103 & 1.754 \\
\hline $10-14$ & 2.187 & 2.170 & 1.803 & 1.772 & 1.454 & 1.323 & 1.277 \\
\hline $15-19$ & 822 & 1.015 & 926 & 908 & 891 & 848 & 970 \\
\hline $20-29$ & 520 & 789 & 867 & 759 & 822 & 757 & 810 \\
\hline $30-49$ & 161 & 293 & 354 & 365 & 450 & 463 & 512 \\
\hline $50-99$ & 37 & 83 & 108 & 104 & 159 & 189 & 228 \\
\hline 100 in več & 12 & 11 & 13 & 8 & 13 & 22 & 35 \\
\hline
\end{tabular}

\section{Vir: SURS 2017.}




\section{Pretežni namen kmetijske pridelave na družinskih kmetijah}

Zelo opazna je sprememba v pretežnem namenu kmetijske pridelave družinskih kmetij v Sloveniji $\mathrm{z}$ »za lastno porabo« na »za prodajo« (tabela 4.11). Čeprav velik delež manjših družinskih kmetij v večji meri prideluje za lastno porabo, večje kmetije, ki uporabljajo večino kmetijskih zemljišč, pridelujejo za prodajo. To spet potrjuje strukturne spremembe znotraj družinskih kmetij, katerih število se zmanjšuje, vendar se hkrati povečuje število družinskih kmetij, ki v pretežni meri pridelujejo za prodajo na trgu. Zaradi vse večje komercializacije družinskih kmetij je prodaja za trg s treh četrtin kmetijskih zemljišč v uporabi v Sloveniji.

Tabela 4.II: Pretežni namen kmetijske pridelave družinskih kmetij v Sloveniji

\begin{tabular}{lccccc} 
& 2005 & 2007 & 2010 & 2013 & 2016 \\
\hline Za lastno porabo & \multicolumn{7}{c}{ Število kmetijskih gospodarstev } \\
\hline Za prodajo & 52.767 & 45.574 & 44.426 & 42.976 & 40.149 \\
\hline \multicolumn{7}{c}{ Kmetijska zemljišča v uporabi (ha) } & & 29.523 \\
\hline Za lastno porabo & 24.274 & 29.635 & 29.999 & 29.200 & 115.819 \\
\hline Za prodajo & 207.106 & 158.257 & 127.564 & 127.822 & 338.242 \\
\hline
\end{tabular}

\section{Vir: SURS 2017.}

\section{Integriranje dohodkov v sodobni kmečki ekonomiji}

Integriranje dohodkov $\mathrm{v}$ sodobni kmečki ekonomiji je močno povezano in odvisno od prodaje kmetijskih proizvodov s kmetije, od zaposlitev $\mathrm{v}$ nekmetijskih dejavnostih in od subvencij, ki so povečevale neto dohodek kmetije. Slovenija se poleg Luksemburga, Češke, Finske in Švedske uvršča med države $\mathrm{z}$ največjimi subvencijami $\mathrm{v}$ neto dohodku kmetije, ki presega 150 \% neto dohodka kmetije (OECD 2016).

Slovenske družinske kmetije, ki so relativno majhne, so v povprečju visoko subvencionirane. Bojnec in Latruffe (2013) sta ugotovila, da je bila pred vstopom Slovenije v Evropsko unijo in po njem tehnična učinkovitost slovenskih kmetij pozitivno povezana $\mathrm{z}$ velikostjo kmetije. Majhne kmetije so tehnično manj učinkovite, so pa bolj alokativno učinkovite in dobičkonosne. Obstoj majhnih kmetij bi lahko bil povezan s subvencijami, ki 
so negativno povezane s tehnično učinkovitostjo, toda pozitivno $\mathrm{z}$ njihovo dobičkonosnostjo. Zmanjšanje števila srednjih kmetij po vstopu Slovenije v Evropsko unijo bi lahko pojasnili z dejstvom, da srednje kmetije vključujejo vse pomanjkljivosti glede obnašanja: so premajhne, da bi bile ekonomsko učinkovite, toda prevelike, da bi bile dobičkonosne.

Družinske kmetije še zmeraj $\mathrm{v}$ večji meri delujejo $\mathrm{z}$ zaposlovanjem lastne delovne sile, medtem ko podjetja in korporacije $\mathrm{v}$ glavnem delujejo na zaposlovanju delovne sile izven kmetije oz. korporativnega podjetja. Čeprav so tako družinske kmetije kot korporacije močno odvisne od subvencij, večji delež subvencij konča $\mathrm{v}$ velikih družinskih kmetijah in predvsem v velikih korporacijah, ki imajo poleg večjega deleža kmetijske zemlje v uporabi in večjega števila živine, na kar so vezana direktna plačila, tudi večje človeške in druge vire ter znanja, da se uspešno prijavijo in pridobijo javna sredstva oz. različne možne subvencije.

\section{Statistično spremljanje integriranja dohodkov v sodobni kmečki ekonomiji}

Za statistična spremljanja integriranja dohodkov v sodobni kmečki ekonomija je pomembna EU-tipologija kmečkega gospodarstva, ki jo uporablja uradna statistika za tekoče statistične podatke, popise kmečkih gospodarstev (angl. Farm Structure Survey, FSS) in za spremljanje računovodskih podatkov za vzorec kmetij (angl. Farm Accountancy Data Network - FADN). Kljub neenotnim teoretičnim pogledom in posameznim nerešenim vsebinskim vprašanjem glede integriranja dohodkov v sodobni kmečki ekonomiji je za potrebe statističnih spremljanj definirano kmečko gospodarstvo ali tipologija kmetije kot enotna klasifikacija kmečkih gospodarstev v Evropski uniji (Eurostat 2017). EU-tipologija za FADN-podatke in statistične podatke vključuje klasifikacijsko spremenljivko druge pridobitne dejavnosti (angl. other gainful activities, OGA), ki so direktno povezane s kmečkim gospodarstvom.

FSS pluriaktivnost opredeljuje kot koncept, ki se nanaša na gospodarja-upravitelja kmetije z obstojem dopolnilne dejavnosti na kmetiji, ki ni dejavnost, povezana $\mathrm{z}$ delom $\mathrm{v}$ kmetijstvu, ki se izvaja za plačila, kot so zunanja zaposlitev in ustanovitev turističnih dejavnosti. Leta 2005 je bilo 36 \% gospodarjev-upravljavcev družinskih kmetij v državah EU-27 vključenih $\mathrm{v}$ pluriaktivnost, kar je bolj posebnost malih kmetij (Barthomeuf 2008; Eurostat 2017). 
Tabela 4.I2: Število družinskih kmetij z dopolnilno dejavnostjo na družinskih kmetijah

\begin{tabular}{|c|c|c|c|c|c|c|c|}
\hline & 2000 & 2003 & 2005 & 2007 & 2010 & 2013 & 2016 \\
\hline Dopolnilne dejavnosti - skupaj & 3.987 & 2.867 & 3.146 & 3.116 & 12.517 & 11.676 & 12.486 \\
\hline Predelava mesa & 221 & 101 & 189 & 68 & 155 & 337 & 257 \\
\hline Predelava mleka & 247 & 115 & 185 & 129 & 242 & 241 & 264 \\
\hline Predelava sadja in zelenjave & 394 & 354 & 390 & 525 & 502 & 342 & 403 \\
\hline $\begin{array}{l}\text { Druge dejavnosti, povezane s } \\
\text { predelavo hrane }\end{array}$ & 172 & 104 & 200 & 219 & 1637 & 1135 & 623 \\
\hline Predelava lesa & 699 & 508 & 449 & 398 & 513 & 520 & 415 \\
\hline $\begin{array}{l}\text { Opravljanje storitev s kmetijsko } \\
\text { mehanizacijo za druge }\end{array}$ & 750 & 905 & 796 & 689 & 310 & 262 & 243 \\
\hline $\begin{array}{l}\text { Turizem na kmetijskem } \\
\text { gospodarstvu }\end{array}$ & 692 & 675 & 628 & 655 & 642 & 726 & 665 \\
\hline Domača obrt (ročno delo) & 268 & 130 & 171 & 165 & 167 & 181 & 153 \\
\hline Ribogojstvo & 75 & 13 & 13 & $\mathrm{z}$ & 28 & 61 & 20 \\
\hline Gozdarske storitve & 200 & 98 & 300 & 360 & 173 & 239 & 153 \\
\hline $\begin{array}{l}\text { Gozdarstvo in trgovina z lesom } \\
\text { (prodaja lesnih izdelkov) }\end{array}$ & 104 & 26 & 80 & 28 & 9078 & 8705 & 9809 \\
\hline $\begin{array}{l}\text { Komunalne storitve (javne } \\
\text { gospodarske službe) }\end{array}$ & 330 & 149 & 297 & 491 & 328 & 391 & 626 \\
\hline $\begin{array}{l}\text { Proizvodnja in trženje energije iz } \\
\text { obnovljivih energetskih virov }\end{array}$ & $\cdots$ & 38 & 79 & 58 & 78 & 96 & 167 \\
\hline Drugo & $\ldots$ & 17 & 16 & 174 & 407 & 81 & 303 \\
\hline
\end{tabular}

\section{Vir: SURS 2017.}

FSS diverzifikacijo dejavnosti kmetije opredeljuje kot koncept, povezan s kmetijskim gospodarstvom, z ustvarjanjem kakršnekoli pridobitne dejavnosti, ki ne zajema kmetijskega dela, temveč je neposredno povezana s kmetijskim gospodarstvom. Leta 2005 je bilo v državah EU-2712 \% kmetijskih gospodarstev ali kmetij, ki so se ukvarjale $\mathrm{z}$ diverzifikacijsko dejavnostjo kmetije, kar je odvisno od velikosti kmetijskega gospodarstva in vrste kmetovanja. Diverzifikacijska dejavnost je bolj razširjena na velikih kmetijah. Predelava kmetijskih proizvodov je najbolj razširjena dejavnost diverzifikacije, in sicer na 55,8 \% kmetijskih gospodarstev v državah članicah EU-27, na primer v Italiji na 84,0 \% kmetijskih gospodarstev in na Madžarskem na 62,7 \% kmetijskih gospodarstev. Poleg tega je 7,1 \% kmetijskih gospodarstev $\mathrm{z}$ diverzifikacijsko dejavnostjo $\mathrm{v}$ državah članicah EU-27 to razvijalo v turizmu, na primer v Avstriji $35 \%$ kmetijskih gosp- 
odarstev, na Švedskem 22,8 \% kmetijskih gospodarstev in v Sloveniji 20,0 \% kmetijskih gospodarstev (Barthomeuf 2008; Eurostat 2017).

V letu 2016 je bilo v Sloveniji 12.486 družinskih kmetij z dopolnilno ali drugo pridobitno dejavnostjo na družinskih kmetijah (tabela 4.12). Kljub zmanjševanju števila družinskih kmetij se je njihovo število z dopolnilno dejavnostjo v zadnjih letih precej povečalo. Največ družinskih kmetij $\mathrm{z}$ dopolnilno dejavnostjo je bilo vključenih $\mathrm{v}$ gozdarstvo oz. $\mathrm{v}$ prodajo lesnih proizvodov. Na slovenskih družinskih kmetijah so bile pomembne tudi druge dopolnilne dejavnosti, povezane s predelavo hrane, s turizmom na kmetijskem gospodarstvu, s predelavo lesa, s komunalnimi storitvami, s predelavo sadja in zelenjave, s predelavo mesa, $s$ predelavo mleka, $\mathrm{s}$ kmetijskimi in gozdarskimi storitvami za druge, $\mathrm{z}$ obrtjo, s proizvodnjo obnovljive energije, $\mathrm{z}$ ribogojstvom in $\mathrm{z}$ drugimi pridobitnimi dejavnostmi na družinskih kmetijah.

\section{Subvencije in državni transferji pri integriranju dohodkov v sodobni kmečki ekonomiji}

Reforme skupne kmetijske politike v Evropski uniji so spremenile vsebine in ukrepe kmetijskih subvencij, saj so neposredna plačila po površini ali na glavo živine nevezana na obseg proizvodnje. Državne subvencije so postale pomemben element prihodkov kmetij in kmetijskih gospodarstev $\mathrm{v} \mathrm{dr}$ žavah članicah Evropske unije (European Commission 2015). Na primer, v letu 2014 je bila odstotna ocena podpore pridelovalcev (angl. \% Producer Subsidy Equivalent), ki predstavlja transferje politik za kmetijske proizvajalce, izražena kot delež bruto prejemkov kmetij, 18,1 \% za države EU-28, 49,5 \% za Japonsko in 60,2 \% za Norveško (OECD 2016). Razvoj kmetijskih gospodarstev in kmetijstva ter raznolikost dohodkov kmetijskih gospodarstev sta pomembno povezana s subvencijami pri integriranju dohodkov kmečkih gospodarstev in s subvencijami za prestrukturiranje ter diverzifikacijo dejavnosti kmečkih gospodarstev in za naložbe v razvoj na podeželju.

Delež nekmetijskih dohodkov v celotnem dohodku kmečkih gospodarstev se je povečeval v razvitih državah in znaša okrog ali več kot $75 \%$ na Švedskem in Finskem. Tudi v Veliki Britaniji, na Irskem in Danskem je delež večji kot $50 \%$. Približno toliko znaša tudi na Madžarskem konec 9o. let prejšnjega stoletja (Eurostat 2017). 
Kmetijske subvencije in subvencije za razvoj podeželja v Sloveniji predstavljajo približno enak delež celotnega prihodka kmetij kot tisti del, ki ga kmetijska gospodarstva dosežejo s prodajo kmetijskih proizvodov (Bojnec in Fertő 2017). Razvoj kmečkih gospodarstev in njihova življenjska raven sta tako pomembno odvisna od diverzifikacije dohodkov kmečkih gospodarstev, ki jih dosegajo z dohodki izven kmetijstva in subvencij, ki so povezane $\mathrm{z}$ reformami kmetijske politike in politike razvoja podeželja ter $\mathrm{s}$ strukturno-kohezijskimi sredstvi, namenjenimi za uravnoteženejši regionalni razvoj. Med dohodki izven kmetijske dejavnosti pa so predvsem pomembni nekmetijske dopolnilne dejavnosti na kmečkem gospodarstvu in nekmetijske zaposlitve ter s tem povezani dohodki na kmečkem gospodarstvu in izven njega. Subvencije naj bi v večji meri prispevale k pozitivnim eksternalijam oz. pozitivnim učinkom za družbo $\mathrm{z}$ večfunkcionalnostjo kmečkega gospodarstva in kmetijstva ter trajnostno naravnanim razvojem podeželja, in sicer z različnimi proizvodi in storitvami, povezanimi s kulturno krajino in zgodovinsko dediščino na vaseh ter na podeželju, z boljšo kakovostjo kmetijskega in življenjskega okolja (zemlja, zrak in voda), večjo urejenostjo in obdelanimi kmetijskimi površinami v podeželski pokrajini in z biodiverziteto. Dolgoročni trajnostni razvoj kmetijstva in podeželja se osredotoča na ekonomske, socialne in okoljske vidike dolgoročnega razvoja, pri čemer lahko vključuje še druge vidike trajnostnega upravljanja, na primer povezanost $s$ kulturno-zgodovinskimi dogodki in $\mathrm{z}$ danostmi $\mathrm{v}$ podeželskem okolju, ki pa se lahko financirajo še iz drugih zasebnih in javnih virov.

\section{Sklep}

Iz prispevka izhaja pomanjkanje teoretičnih in strokovnih spoznanj pri raziskovanju integriranja dohodkov v sodobni kmečki ekonomiji. Zaradi večje razpložljivosti podatkov se to pogosto osredotoča na raziskovanje dopolnilnih dejavnosti na kmetiji. Zato so ključnega pomena opredelitev in definiranje dopolnilnih dejavnosti na kmetiji ter učinki, ki so s tem povezani. Gre za interdisciplinarna raziskovalna vprašanja, ki so prepletena $\mathrm{z}$ ekonomijo, agrarno ekonomiko, s podjetništvom in $\mathrm{z}$ razvojem podeželja, pravno-organizacijskimi in drugimi interdisciplinarnimi vprašanji trajnostnega razvoja kmečkih gospodarstev in razvoja podeželja.

Predstavljene so hitre strukturne spremembe $\mathrm{v}$ kmetijstvu, na kmetijskih gospodarstvih in na podeželju v državah EU-28, med katere spada tudi Slovenija: upad števila kmetij oz. kmetijskih gospodarstev, po ob- 
segu uporabljenih dejavnikov in po velikosti proizvodnje povečanje njihove povprečne velikosti, povečana specializacija in komercializacija proizvodnje ter hiter porast integriranja dohodkov kmečkih in tudi nekmečkih gospodarstev na podeželju. Znotraj držav EU-28 in med njimi soobstajajo razlike v strukturi kmetij. Razlike so med državami $\mathrm{z}$ notranjo dualnostjo $\mathrm{s}$ številnimi malimi in $\mathrm{z}$ nekaj velikimi kmetijami. Soobstoj teh razlik in njihova evolucija se lahko pojasnijo $\mathrm{z}$ njihovo različno ekonomsko, socialno in okoljsko vlogo ter učinki, ki jih različne strukture kmetij igrajo ne samo pri proizvodnji hrane, ampak tudi v ohranjanju kulturne krajine in naravnih virov, podeželskih skupnosti, kulture in tradicije v podeželski ekonomiji, kar naj bi se posebej spodbujalo s subvencijami za kmetijstvo in razvoj podeželja.

Prispevek je osredotočen na integriranje dohodkov v sodobni kmečki ekonomiji na podeželju s poudarkom na državah EU-28 in znotraj tega posebej na analizo ter mednarodne primerjave obstoječega stanja $s$ Slovenijo. Diverzifikacija dohodkov kmečkih gospodarstev je odvisna od strukture kmetijske proizvodnje in s tem od prestrukturiranja znotraj kmetijske proizvodnje, drugih pridobitnih dejavnosti na kmečkem gospodarstvu in dohodkov od izvenkmetijske zaposlenosti v državi ter izven nje, ki so povezani $z$ dnevnimi, občasnimi in stalnimi migracijami ter s tem povezanimi nakazili na kmečko gospodarstvo. Evidence o prilivih iz tujine so omejene in jih nismo posebej analizirali, kar je možnost za nadaljnje raziskovanje. V novejšem času to še posebno velja za vzhodno kohezijsko regijo v Sloveniji, kjer so številne dnevne migracije na delo zlasti na avstrijsko Štajersko.

Različne dopolnilne dejavnosti so $\mathrm{v}$ kmečkih gospodarstvih razvite kot lokalna ponudba proizvodov in storitev, $\mathrm{v}$ povezavi $\mathrm{z}$ nekmetijskimi podjetniškimi dejavnostmi izven kmečkega gospodarstva in pri zagotavljanju storitev trajnostnega razvoja podeželja. Vse pomembnejši vir dohodka kmečkih gospodarstev so vladni transferji z različnimi implikacijami za kmetije, kmetijstvo in gospodarstvo na podeželju. Integriranje dohodkov $\mathrm{z}$ nekmetijskimi dohodki in subvencijami lahko prispeva $\mathrm{k}$ ohranitvi kmetijstva in obdelovalnih površin na območjih $\mathrm{z}$ omejenimi dejavniki za kmetijsko proizvodnjo ter k zmanjšanju odhajanja mladih s kmetij. Zmanjševanje števila kmetij in porast njihove povprečne velikosti s povečano specializacijo in komercializacijo kmetijske proizvodnje je mogoče pričakovati tudi v prihodnje. Če je bilo za slovenske družinske kmetije tipično, da je imelo vsako kmečko gospodarstvo vsaj eno ali dve kravi za hrano, pridelano na kmetiji, in za občasno uporabo za razna kmečka dela 
na kmetiji, kot sta krajši prevozi in oranje, je vse bolj, zlasti v posameznih vaseh v ravninskem delu Slovenije, kjer so različne subvencije za mleko nižje, težko najti kmečko gospodarstvo, ki ima v hlevu krave, seveda ne več za delo na kmetiji, ampak za prodajo mleka in telet ter goveda. Nadaljnji razmah strukturnih sprememb in s tem povezanega integriranja dohodkov na kmečkih gospodarstvih je mogoče pričakovati od nadaljnjega razvoja na trgu najema zemlje, katerega pomen narašča in tako je razlika med lastništvom in obdelavo zemlje vse večja, kar je tudi tipično za nekatere stare članice Evropske unije, kot so Francija in države Beneluksa. Obstoj in nadaljnji razvoj kmečkih gospodarstev s kmetijsko proizvodnjo pa je vse bolj odvisen od subvencij, medtem ko so za poseljenost podeželja vse pomembnejša nekmečka gospodarstva, ki predvsem integrirajo dohodke iz nekmetijskih dejavnosti na podeželju in iz dela v mestih ter v tujini.

Ustrezna ureditev in učinkovito delovanje dopolnilnih dejavnosti na kmetiji je še zmeraj odprto vprašanje ekonomske in kmetijske politike. Gre za interdisciplinarno raziskovalno in strokovno praktično vprašanje s pravno-organizacijskega in ekonomskega vidika ter vprašanje agrarno-ekonomskih posledic za razvoj kmetij z dopolnilnimi dejavnostmi in za razvoj podeželja. Iz pravno-organizacijskega statusa dopolnilnih dejavnosti na kmetiji izhajajo tudi ekonomske posledice za dohodek kmetije, socialno varnost zaposlenih, razvoj podeželja in na davčnem področju. Dopolnilne dejavnosti na kmetiji se pogosto prepletajo in konkurirajo s podobnimi dejavnostmi drugih udeležencev na lokalnem trgu, in sicer s samostojnimi podjetniki in podjetji. Pogoji med različnimi subjekti, ki so registrirani kot dopolnilna dejavnost na kmetiji, in subjekti, ki so registrirani kot podjetja oz. gospodarske družbe in samostojni podjetniki, se lahko razlikujejo, kar lahko vpliva na konkurenco med njimi in s tem na razvoj podjetništva na podeželju, kot na primer turizem na kmetijah in turizem pri drugih ponudnikih turističnih storitev na podeželju. Ekonomski pogoji za poslovanje se zlasti razlikujejo zaradi različnih obdavčitev in obremenitev s prispevki za socialno varstvo dopolnilnih dejavnosti na kmetiji z enakimi dejavnostmi drugih udeležencev na lokalnem trgu, kot so samostojni podjetniki in podjetja.

$\mathrm{V}$ zadnjih letih se posebna pozornost posveča evidencam, ki bi prikazale dopolnilne dejavnosti in integriranje dohodkov kmečkih gospodarstev. Med te statistične podlage se lahko uvrstijo nacionalne in Eurostatove statistike za države EU-28, vključno s popisi kmečkih gospodarstev in podatki FADN. Za sam razvoj in integriranje dohodkov kmečkih in podeželskih 
gospodarstev so pomembni spodbuden pravno-institucionalni okvir glede pogojev in mehanizmov upravljanja dejavnosti, odstranjevanje administrativnih težav in ureditev statusa dopolnilnih dejavnosti na kmetiji za njihov lažji razvoj ter nove vstope $\mathrm{v}$ dejavnost in posledično $\mathrm{s}$ tem ustvarjanje novih delovnih mest ter dohodka na kmetijah in na podeželju. Pomembno pa je tudi ciljno usmerjeno trženje proizvodov in storitev dopolnilnih dejavnosti na kmetiji ter promocija za doseganje večje učinkovitosti dopolnilnih dejavnosti na kmetijah ter s tem posledično dolgoročneje in trajnostneje umerjeni razvoj dopolnilnih dejavnosti na kmetijah. Dopolnilne dejavnosti na kmetijah so pomemben vir zaposlitev in dohodka za številne kmetije in s tem prispevajo k poseljenosti krajine ter trajnejšemu razvoju podeželja. V primeru novih naložbenih dejavnosti je lahko njihov razvoj pomembno povezan tudi s strukturno-kohezijskimi politikami in njihovimi naložbenimi ukrepi za bolj usklajen regionalni razvoj.

\section{Literatura}

Barthomeuf, L.-T. 2008. Other Gainful Acitivites: Pluriactivity and Farm Diversification in EU-27. Brussels: European Commission - AGRI G2.

Bojnec, Š. 2017. »Pluriactivity, Part-Time Farming, Farm Diversification, Integrated and Inclusive Rural Household Development in Contemporary Economics. V Integrated Peasant Economy in a Comparative Perspective: Alps, Scandinavia and Beyond, uredili A. Panjek, J. Larsson in L. Mocarelli, 415-36. Koper: University of Primorska Press.

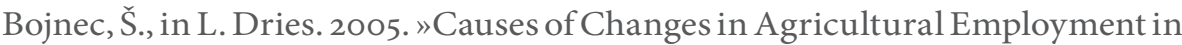
Slovenia: Evidence from Micro-Data.« Journal of Agricultural Economics 56 (3): 399-416.

Bojnec, Š., in I. Fertő. 2017. »The Impact of CAP Reform on Farm Household Income in Slovenia.« Prispevek na 15. European Assocation of Agricultural Economists Congress, Parma, 28. avgust-1. september 2017.

Bojnec, Š., in L. Latruffe. 2013. „Farm Size, Agricultural Subsidies and Farm Performance in Slovenia.« Land Use Policy 32: 207-17.

Bull, A., in P. Corner. 1993. From Peasant to Entrepreneur: The Survival of the Family Farm in Italy. Oxford: Berg.

Campagne, P., G. Carreere in E. Valceschini. 1990. »Three Agricultural Regions of France: Three Types of Pluriactivity." Journal of Rural Studies 6 (4): $415-22$. 
Davis, B., P. Winters, G. Carletto, K. Covarrubias, E. J. Quinones, A. Zezza, K. Stamoulis, C. Azzarri in S. Digiuseppe. 2010. "A Cross-Country Comparison of Rural Income Generating Activities."World Development 38 (1): 48-63.

Ellis, F. 1998. »Household Strategies and Rural Livelihood Diversification.« Journal of Development Studies 35 (1): 1-38.

Ellis, F. 200o. Rural Livelihoods and Diversity in Developing Countries. Oxford: Oxford University Press.

European Commission. 2015. EU Agriculture Spending: Focused on Results. Brussels: European Commission - Agriculture and Rural Development. http://ec.europa.eu/agriculture/cap-funding/pdf/ cap-spending-09-2015_en.pdf.

Eurostat. 2017. Agriculture Database. Luxembourg: Eurostat. http://ec.europa. eu/eurostat/web/agriculture/data/database.

Francks, P. 1995. "From Peasant to Entrepreneur in Italy and Japan." The Journal of Peasant Studies 22 (4): 699-709.

Graeub, B. E., M. J. Chappell, H. Wittman, S. Ledermann, R. Bezner Kerr in B. Gemmill-Herren. 2016. »The State of Family Farms in the World.« World Development 87: 1-15.

Kinsella, J., S. Wilson, F. De Jong in H. Renting. 200o. »Pluriactivity as a Livelihood Strategy in Irish Farm Households and Its Role in Rural Development.« Sociologia Ruralis 40 (4): 481-96.

Knific, K., in Š. Bojnec. 2015. »Agricultural Holdings in Hilly-Mountain Areas in Slovenia before and after the Accession to the European Union." Eastern European Countryside 21 (1): 19-34.

Krašovec, S., ur. 1982. Part-Time Farmers and Their Adjustment to Pluriactivity: Proceedings of the Seminar on Mixed Households, held on 21th-24th June 1981 at Ljubljana. Ljubljana: Slovenian Academy of Sciences and Arts.

OECD. 2016. Producer and Consumer Support Estimates Database. Paris: Organisation for Economic Cooperation and Development. http://www. oecd.org/tad/agricultural-policies/producerandconsumersupportestimatesdatabase.htm.

Panjek, A., J. Larsson in L. Mocarelli, ur. 2017. Integrated Peasant Economy in a Comparative Perspective: Alps, Scandinavia and Beyond. Koper: University of Primorska Press.

SURS. 2017. Statistični urad Republike Slovenije, portal SI-STAT. Ljubljana: Statistični urad Republike Slovenije, http://pxweb.stat.si/pxweb/dialog/ statfile2.asp. 
van der Ploeg, J. D., in Y. Jingzhong. 2010. "Multiple Job Holding in Rural Villages and the Chinese Road to Development.« The Journal of Peasant Studies 37 (3): 513-30.

"Zakona o kmetijstvu." Uradni list RS, št. 45/o8, 57/12, 90/12, 26/14, 32/15). 